\title{
Sustainability and urban sprawl: Alternative scenarios for a Bangkok superblock
}

\author{
Sidh Sintusingha* \\ Faculty of Architecture, Building and Planning, University of Melbourne, Victoria 3010, Australia
}

\begin{abstract}
How do we plan/design cities towards a more sustainable future? This paper illustrates application of an alternative design scenario on a Bangkok 'superblock', identified as Bangkok's unit of lateral expansion. Through the process, Bangkok's suburbanization pattern is analyzed and, based on this growth-pattern, a probable future scenario of unmediated change is generated. A 'generic' model of the sustainable city is synthesized from the literature and is then applied to and adapted for Bangkok to generate a 'mediated change' and both are then compared. The 'mediated change' scenario aims to 'retrofit' Bangkok's (sub)urbanization patterns - plotting paths towards 'sustainability' specific to Bangkok's socio-economic context. In the tradition of alternative design visions of the future as major contributions to knowledge, this process provides a heuristic device to inform and assist practitioners, decision makers and stakeholders in navigating, engaging with and applying the metanarrative of sustainability at a local level.

URBAN DESIGN International (2006) 11, 151-172. doi:10.1057/palgrave.udi.9000174
\end{abstract}

Keywords: sustainability; urban sprawl; developing cities; Bangkok superblocks; alternative future scenario method

\section{Introduction}

There has been a clear bias on issues concerning sustainability in the urban context, towards the more established and 'developed' Western city, rather than 'developing' Asian cities, which are growing at historically unprecedented rates. If sustainability is to have true global depth and validity in practice, it must be malleable enough, in its meanings and forms, to dynamically address, balance and mediate unavoidable inconsistencies between the generic and specifics; ecocentric and anthropo-centric worldviews; scales of intervention, comprehensive visions and incremental actions through the diverse and complex spaces of socio-economic and cultural differences. In this globalizing world, the homogenization of urban practices is one of the root causes of current ills, but at the same time globalization's communication technologies provide the means by which future resolutions that arise may be perpetuated, expanded, multiplied and differentiated into

\footnotetext{
*Correspondence: Tel: 61-3-8344-7191, Fax: 61-3-8344-5532. E-mail: ssint@unimelb.edu.au
}

locally sensitive global solutions in the best tradition of sustainable development.

To embrace sustainability, we should see each Asian city, or any other city for that matter, as individuals with their peculiarities and eccentricities - a mixture of indigenous urban traditions and ecological characteristics, which often clash with the overlay of modern urban practices. Attempts at unraveling the adverse impacts of unsustainable practices need to be grounded in a thorough analysis and understanding of the urban history of each city. Those specific narratives of each city would have to be integral in the sustaining trajectory of the city's future development.

Even within each city, there are high degrees of differentiation and fragmentation. This is especially true in developing countries where economic stratification is pronounced and is physically manifested (Herbert and Thomas, 1997, pp. 51-56). Thus, any attempts at sustainable practice must be tailored to the particularities, not just of cities in general but also to each of the city's parts, bits or fragments, which may have their own localized narratives. So it is with 
Bangkok, the topic of this paper, where a design/ reorganization of the case 'superblock', located in Bangkok's northeastern fringe, is proposed. This proposition suggests how sprawl may be restructured, retrofitting to improve (and perpetuate) the sustainability of settlement forms.

Urban sprawl poses some of the most critical challenges for urban sustainability and is a common global phenomena tied in closely with economic and population growth. Moreover, urban sprawl is arguably one of the critical meeting points of globalization, un-sustainability and local cultures manifested in the form of preexisting patterns varyingly erased and assimilated by sprawl. This paper argues that in order to move towards the objectives of urban sustainability, the on-ground realities of urban sprawl need to be proactively addressed and innovative sustainable retrofits are desirable.

In this paper, this is achieved by the application of an alternative scenarios method as a heuristic device. It begins by identifying the typical components of the Bangkok superblock 'as is', projecting a future form from there in 20 years, from the time of the case survey in 2001, if current development patterns persist. The 'as is' representation also addressed the past process of change leading to the present. Development precedents nearby (nearer the urban core) are considered when projecting the future form. An alternative is then proposed, addressing each component as the 'local' ingredients of a reorganized and restructured superblock design, if sustainable practices were the objective.

\section{Sustaining Bangkok equates with sustaining Thailand}

Bangkok has always been considered a primate city $^{1}$ - a city that dominates its country economically, socially and culturally, and is, according to Sternstein (1982, p. 109), the 'world's pre-eminent primate city'. This is even more so today after Thailand, an ardent participant of globalization, has experienced decades of unprecedented eco-

\footnotetext{
${ }^{1}$ Using the 'disparity' in size between Bangkok and the next largest city as the measuring criterion (Bello et al, 1998, pp. 9596). Moreover, Bangkok begun with clear comparative advantages over the rest of the country of being located in the richest rice-growing area, then, the only deep-sea port in the country (Vichit-Vadakarn and Nakata, 1976, p. 8).
}

nomic growth. ${ }^{2}$ The majority of that growth has resulted in intense urbanization (Hamilton, 2000, p. 461) that has spread into adjacent provinces.

This growth has come at high social and environmental cost. The city has not only invaded the surrounding rural farmlands and plantations, it has also erased them, replacing the pre-existing agrarian lifestyles and ecologies with housing and industry. It exploited resources, natural and human, from far and wide throughout the kingdom and the economically poorer neighboring countries. Thus, the sustainability debate for Thailand must focus on the activities and practices of Bangkok. It is here where environmental deterioration is at its worse as the city's rapid growth 'exceeded supply of infrastructure and services' (Douglass and Zoghlin, 1994, p. 172) with industrialization characterized by 'zero-investment in pollution control' (Bello et al, 1998, p. 74).

\section{'Superblocks': Bangkok's unit of lateral expansion}

Further from the urban core, Bangkok becomes spatially fragmented, characterized by leapfrog developments and 'superblocks' (Figure 1), with empty tracts of land (or 'empty space fragments' in this paper) locked between and within surrounding major road arteries. These superblocks (which can be as large as $20 \mathrm{~km}^{2}$ ) have characterized urban growth since the acceleration of road development in the 1950s and make up the majority of the Metropolitan Region that extends $30-40 \mathrm{~km}$ from the old urban core (Kaothien and Webster, 2000, p. 29).

Bangkok's urban and suburban fragments, typically associated with the city's haphazard and indiscriminate growth, are given some organization through these gigantic grids or superblocks. Along with the shophouses, highrises - whether apartments, condominiums, hospital, office buildings and malls (often in combination with local temporal markets) - now line the major roads and

\footnotetext{
${ }^{2}$ Begun in its commercialized agricultural production and industrialized form in the late 1950s 'under the influence of the World Bank-USAID ideology of developmentalism' (Bello et al, 1998, p. 144) - starting with the phase of importsubstitution, followed by export-oriented growth fueled by foreign direct investments (FDI) particularly from Japan in the $1980 \mathrm{~s}$, and the liberation of the financial sector in the early 1990s (Bello et al, 1998, pp. 6-7).
} 


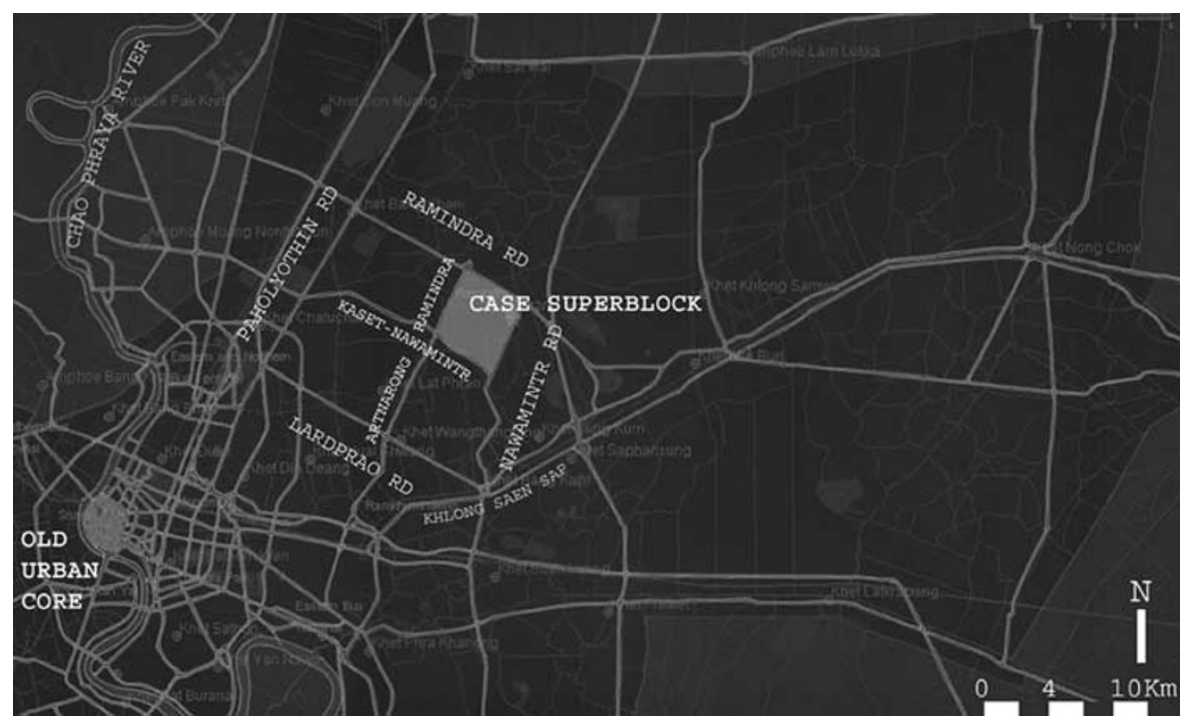

Figure 1. The 'superblock', unit of Bangkok's lateral expansion - the further away from the old urban core, the larger the blocks. The plan also shows the system of main roads, minus soi's, superimposed on to pre-existing, now obscured, khlong's system (Sintusingha, 2004, p. 141).

highways that edges the superblock, functioning as linear cities. Inside, accessible via the system of wriggling, often dead-end, soi's (lanes) are suburban subdivisions (of townhouses, detached houses and a mixture of typologies) and openspace fragments consisting of both idle plots and those utilized for rural functions.

Here it is argued that Bangkok's urban regeneration/reorganization can best be carried out by applying the principles of 'land readjustment' (Bangkok Metropolitan Administration's (BMA)) official tool of choice $^{3}$ ) on these unfilled, openspace fragments within superblocks to achieve the necessary efficiencies leading towards sustainability. Lessons drawn from this process may also be applicable to other Asian cities that experienced similar 'leap-frogging' development.

\section{Design approach}

This paper adopts Berke and Conroy's definition of 'sustainable development' - 'dynamic process in

\footnotetext{
${ }^{3}$ The Land Readjustment Bill has been proposed since 1987 with Japan International Cooperation Agency's (JICA) support until 1992 but has failed to get passed due to both resistances from interest groups and also parliamentary mishaps (Thansettakij, 2004). The more recent protests by Buddhist organizations over the inclusion of temple property in the bill came from misunderstandings/miscommunications/mistrust that the land could be utilized as the (business oriented) government seems fit (Bangprapa, 2004;Thairath, 2004).
}

which communities anticipate and accommodate the needs of current and future generations in ways that reproduce and balance local social, economic and ecological systems, and link local actions to global concerns' (2000, p. 23). Coming from the design/planning discursive location and considering that social, economic and cultural processes manifest physically, the environment is considered the main framework and foundation for mediations towards sustainability. Moreover, narratives of sustainability historically arose and still derive relevance - from global environmental problems and the practical need to engage with the complexities of society and the economy to mitigate those problems.

At the broadest level, the design approach for the superblock discussed here is based on the 'model for sustainability' (Figure 2) whereby cultural and societal functions and practices are mediated towards a circular metabolism. ${ }^{4}$ It is posited here that if the issues of urban sustainability are to be seriously tackled, such a model provides a method or approach to guide change towards such goals. Urban economic, social, environmental and cultural processes and practices are

\footnotetext{
${ }^{4}$ Girardet calls for the city to mimic nature's circular metabolism in which '... every output which is discharged by an organism also becomes an input which renews and sustains the continuity of the whole living environment of which it is a part' (1999, pp. 32-33).
} 


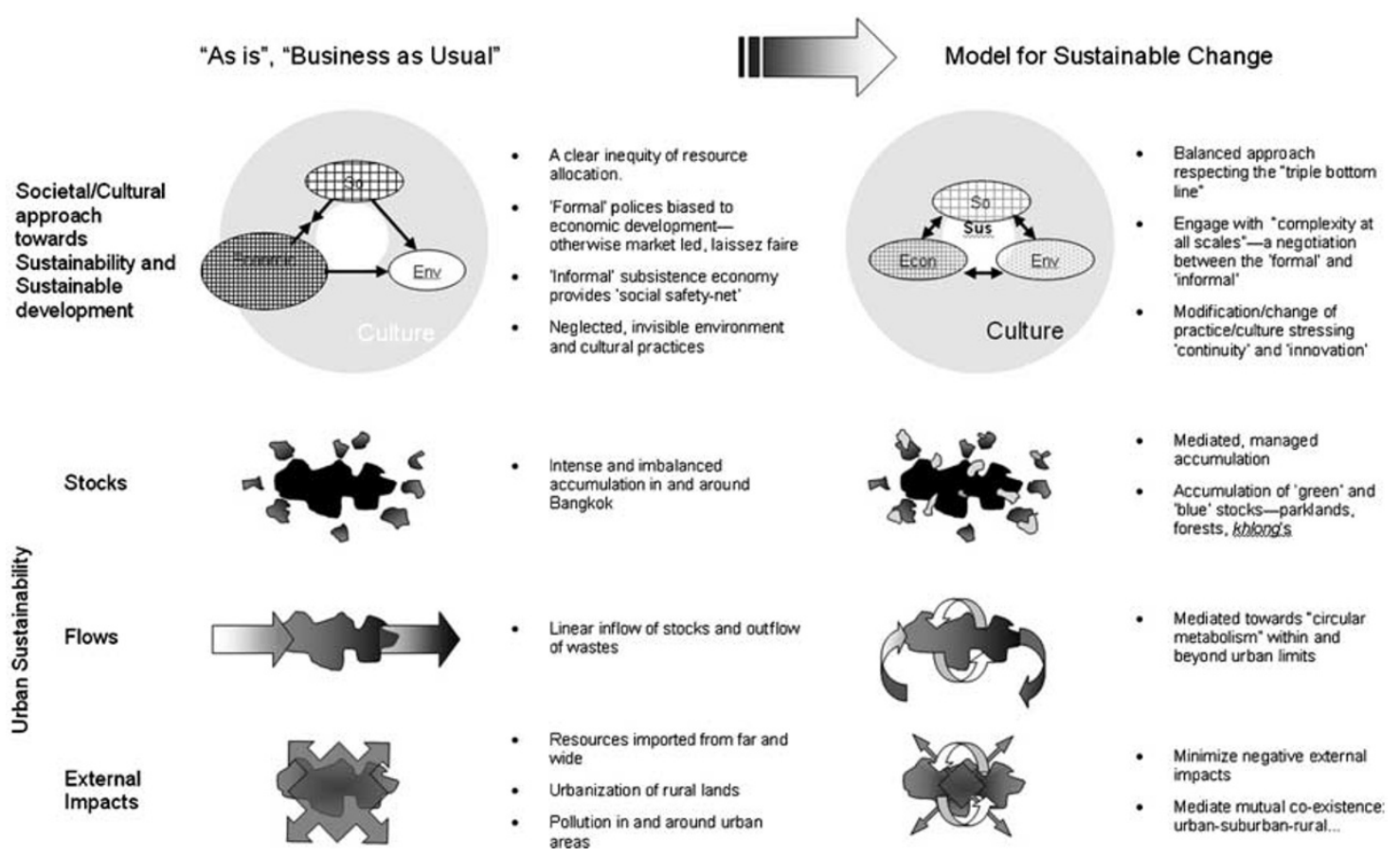

Figure 2. Model for sustainability as process $p$ (by author).

intrinsically interdependent, and giving hegemony to one aspect, particularly the economic, as is the common practice, will always have repercussions on the others and these can often be negative. Such repercussions are often ignored or simply accepted as normal collateral damage as part of economic growth but to progress towards sustainability that needs to change.

Such a model of mediation when applied to the case superblock (Figure 1) starts by documenting and analyzing the site in its contemporary condition (environmental, urban, social and 'cultural') as an 'As Is' representation from which two scenarios are then generated for the year 2020 about 20 years from the original survey undertaken in late 2001 to early 2002. First, an 'Unmediated Change' scenario is generated representing Bangkok's urbanization/suburbanization pattern of multiplying and intensifying of 'superblocks'. This scenario assumes that Bangkok will continue to grow, physically and population-wise, approximately in the manner of the past 20 years. ${ }^{5}$ The critique of this process

\footnotetext{
${ }^{5}$ Determining Bangkok's 'real' population and projecting its growth has always been problematic, due both to the unaccounted immigration (whether in formal or informal settlements) as well as the day-time residences from adjacent provinces which already form parts of Bangkok's conurbations.
}

(the 'As Is' representation) continued as the 'Unmediated Change' scenario is then amalgamated with the precepts from the 'Model for Sustainability' (Figure 2) to generate an 'Alternative Future' scenario (refer to Figure 3).

In the process, the representation and scenarios were subdivided into headings of 'Ecological, rural patterns', 'Road access and urbanization', 'Settlement forms and patterns' and 'Open space, production, community/activities centers', in order to structure the components for the design. Together they form the principle ingredients and fragments addressed in the design/reorganization process that constitute the new superblock. In this paper, only 'Ecological, rural patterns' (Figures 4-6, 10-12, 14-16) will be illustrated across the representation and scenarios, with the scenarios summarized by 'models' (Figures 13 and 17).

The design brief has come about through an analysis of the issues on the ground while concurrently aiming to address the generic, even abstract, principles of sustainability, the systemic issues of sustainable city and the physical sustainable urban form, where the recognizable specificities of place come into play. The brief integrates those analyses, syntheses and issues into the design/reorganization decision-making process, adapted from Steinitz's (1998) 'frame- 


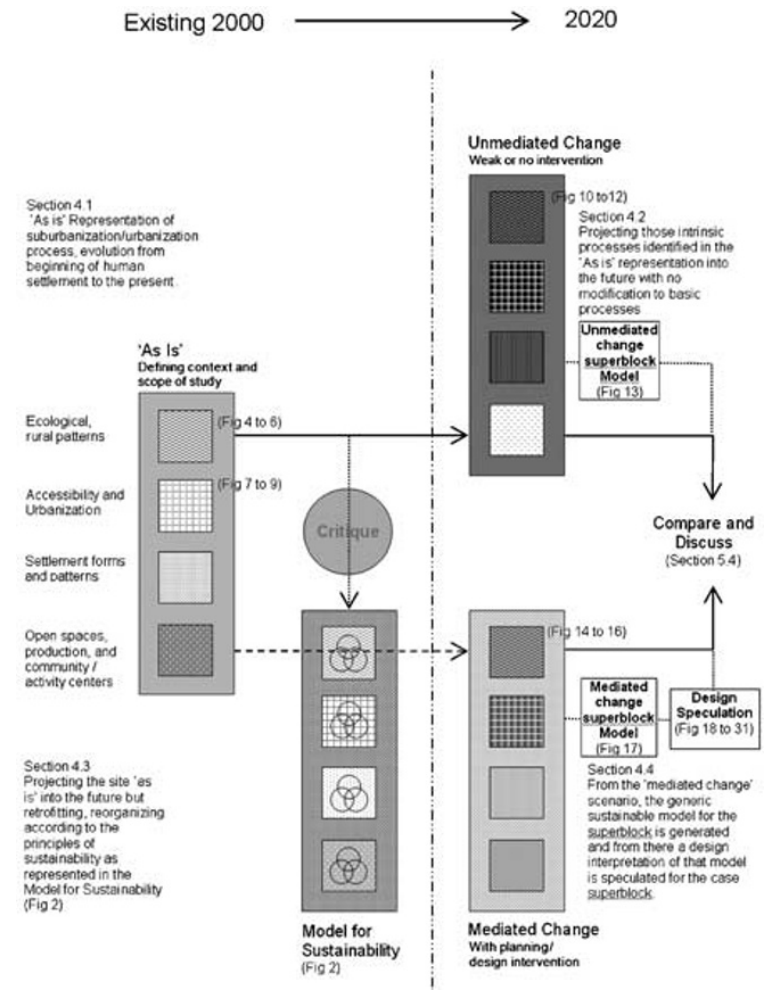

Figure 3. Design strategy for superblock.

work for theory', by progressing through the case superblock three times: the 'as is' representation which identifies the 'context and scope of study'; the 'unmediated change' - which illustrates what could transpire should there be no (or weak) intervention, clarifying the 'method of design' in the process; and, the 'mediated change' scenarios - which provisionally generates a set of possible 'answers'.

The fundamental objectives of the design, reorganization as means towards sustainability are:

- Balance social, economic, environmental and cultural aspects of development, by calling for human development processes that contribute to, rather than to exploit, the environments they change (Hough, 1995; Campbell, 1996; Maclaren, 1996; Girardet, 1999; Newman and Kenworthy, 1999 etc.) and encourage non-utilitarian values in the landscape (Nassauer, 1995; Dearden, 2002).

- Mediate urban stocks, flows and external impacts towards a circular metabolism (Girardet, 1999; Yencken and Wilkinson, 2000) while making those processes visible (Hough,
1995; Nassauer, 1995), given that the best place for environmental education is 'at home' in the city (Hough, 1995, pp. 24-26).

- Mitigate towards a process-oriented (Papanek, 1995; Hagan, 2001) urban forms of Bangkok's superblock by focusing on the city's placespecific ingredients of khlong's and the empty space fragments to mitigate sprawl and create:

- 'Commons' encompassing complementary features of both formal protected areas and community-based systems (Spirn, 1984; Nicholson-Lord, 1987; Breheny, 1992; Nassauer, 1995; Bull, 2002; Dearden, 2002).

- A 'public realm' that will alleviate social/ spatial segregation and encourage functional, social and biological diversity (Yeang, 1986, 2002; Douglass and Zoghlin, 1994; Hough, 1995; Rogers, 1997; Yencken and Wilkinson, 2000).

- An integrated natural system incorporating water, biodiversity, drainage and sewerage treatment with green open spaces (Girardet, 1999; Berke and Conroy, 2000; Yencken and Wilkinson, 2000; Bull, 2002).

- Plots for 'urban farming' (whether it be for subsistence and middle-class farmers), 'urban forestry' (Hough, 1995; Frey, 1999; Girardet, 1999; Rees, 1999).

- Maintain and reinforce existing social-spatial, cultural networks and characteristics, for example, temples, open-air markets and khlong's, also integrating the spiritual realms of temples /masjids / churches in that process (Frey, 1999; Girardet, 1999; Berke and Conroy, 2000).

- Coordinate and reorganize system of khlong's and open-space fragments with urban developments - settlements, urban functions/services, road systems while encouraging/ reinforcing the already vibrant mixed 'complex interweaving of uses and by blurring the distinctions between uses' (Carmona et al, 2002) (Breheny, 1992; Rogers, 1997; Frey, 1999; Berke and Conroy, 2000).

- Integrate mixed-density developments as well as low-cost housing to achieve social diversity (Frey, 1999; Berke and Conroy, 2000).

- Integrate networks of pedestrian/ bicycle/ vendor routes with public transport networks to mitigate private vehicles. This includes the creation of new routes as well as the retrofitting of existing network (Breheny, 1992; Frey, 1999; Yencken and Wilkinson, 2000; Clarke, 2003). 
- The formal categorization and planning/design application of the existing local typologies of superblocks, thanon's, soi's, khlong's, talad's (or 'markets' - including the fine-scaled mobile street vendors of the 'informal sector').

The key 'new' ingredient proposed in the design/ planning process is the planned addition of the 'commons' - formal open spaces that does not merely serve urban recreational and ornamental purposes as is often practiced, but also addresses and encompasses broader ecological, socioeconomic dimensions and functions within (and beyond) the urban fabric. The commons are given priority as a public initiative as they would enhance and transform the lives of the inhabitants of the superblock of all socioeconomic background for the better in terms of sustainable development.

The design/reorganization process argues for a broader scale framework for readjustment 'urban' rather than just the finer scale of 'land readjustment'. It tackles the fundamental components/fragments that constitute Bangkok - the superblocks, the roads, the soi's and the khlong's and the various urban fragments they individually and collectively generate.

The process and planning design outcome serves as a heuristic device for urban planning/design practitioners. Should the process be continued (beyond this paper's focus), the design vision could be further tested in the process of 'backcasting' (Yencken and Wilkinson, 2000, p. 319), where steps, phases and details of mediation are defined, taking the conditions and practices of the present as the starting point, in order to reach while most likely modifying in the process - the end vision.

\section{Representation: 'As is' - existing development patterns; formation of the superblock (discerning the context and scope of study)}

The superblock - bounded by Ramindra Rd. to the north, Nawamintr Rd. to the east, Kaset-Nawamintr highway to the south and Artnarong-Ramindra expressway/highway to the west - is located between 10 and $20 \mathrm{~km}$ northeast of Bangkok's urban core (see Figure 1), an area officially designated as the 'urban fringe' (BMAa, 1999, pp. 2-3). This area is still in the process of 'intensification' - its urban fabric not fully 'developed', having vast tracts of unbuilt openspace fragments, most of which are idle land with a small proportion still agriculturally productive.

The case superblock has an area of approximately $8.97 \mathrm{~km}^{2}$ with, to date, no formally designated public open space; recreation activities have been informally catered to by the soi's, semiformal 'slabs' (concreted spaces off the soi's) and open-space fragments. Bangkok as a whole has $4.83 \mathrm{~km}^{2}$ of formal parklands (combining urban parks, 'forest-gardens' and 'recreational gardens') or around $0.30 \%$ of BMA's total area (BMAa, 1999, pp. 6-31). This is equivalent to $0.862 \mathrm{~m}^{2}$ of public open space per person, which is 'very little compared to cities of similar size' ${ }^{6}$ (BMAa, 1999, pp. 6-31). The distribution of those urban parks is uneven across the city, with most of the parks located in the inner city areas.

Calculating from the base of 5,643 person $/ \mathrm{km}^{2}$ population density of Bungkum district for the year 2000 ((BMAb, 2001, p. 2), ${ }^{7}$ within which most of the case superblock is located, the population of the superblock would have been about 50,618 people.

The representations model the process of transformation of the wilderness into rural lands (Figures 4) followed by the suburbanization/urbanization patterns through the construction of thanon's and soi's, which eventually amalgamate to form superblocks (Figures 7).

\footnotetext{
${ }^{6}$ Los Angeles City has almost $17 \mathrm{~m}^{2}$ of parkland per person with a population density of 3027 people $/ \mathrm{km}^{2}$ (Wolch et al, 2002 , p. 8). Bangkok's 2000 population density is 3621 people/ $\mathrm{km}^{2}$ ((BMA, 2001, p. 2), although the calculation also included the low-density agricultural conservation and flood prone lands that comprise $31.4 \%$ of total area (Anukulyudhathon (2004, p. 1.6) from Faculty of Forestry, Kasetsart University 2003). Other mega-cities such as Tokyo has $3.7 \mathrm{~m}^{2} /$ person, Paris has $12.2 \mathrm{~m}^{2}$ / person, London has $30.4 \mathrm{~m}^{2} /$ person (DUDP, p. 218).

${ }^{7}$ The population density would be 7826 people $/ \mathrm{km}^{2}$ if recalculated for built-up areas only excluding the $27.89 \%$ of agriculture, khlong's (and other bodies of water) and idle lands. The percentage of built/unbuilt area was calculated for Bungkum and the two adjoining districts to the east and southeast of Kannayao and Saphan Sung, respectively (DRTP, 2002, pp. 3-20).
} 


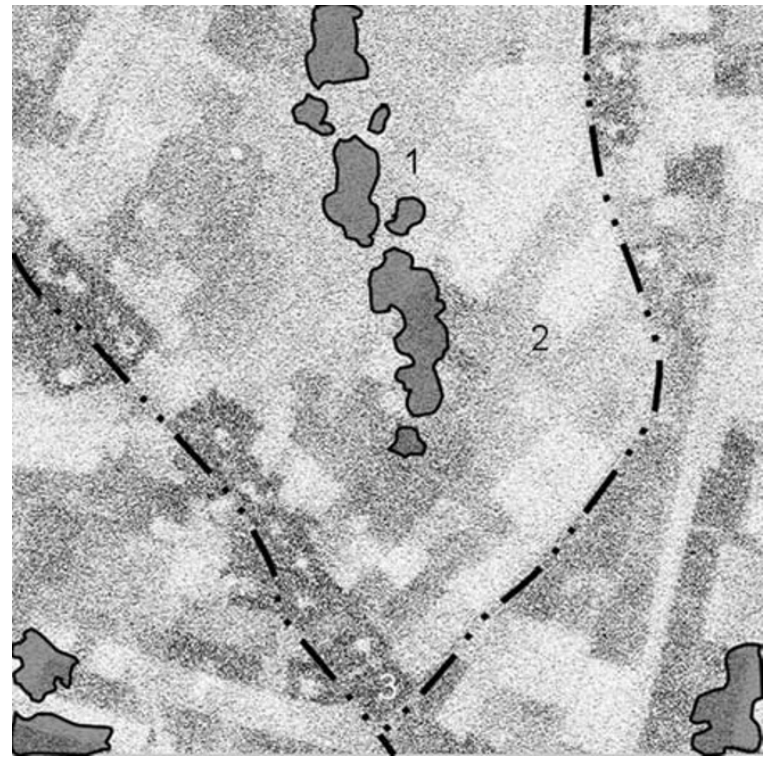

Figure 4. Pattern pre-human settlement (before 1870s).

\section{Ecological, rural patterns}

Generated representation of the pre-human settlement landscape (Figure 4):

1. Clumps of low bush on higher grounds.

2. Savannah grasslands (tung) of the Chao Phraya floodplains. The relatively flat topography is subjected to natural floods, fertile run-off water from the north every September to October, flushing south towards the Gulf of Thailand thus the plain's suitability and eventual utilization as rice fields.

3. Swamps(bung) with natural creeks and drainage lines (Hanks, 1972; Kaufman, 1976).

Generated representation of rural land subdivision pattern (Figure 5):

1. Agricultural land subdivision pattern into sen's (Nimlek, 2002) of predominantly rice paddies.

2. Enhanced drainage lines into khlong's. However, the khlong's in Bangkuad were navigable only during rainy seasons and a complementary network of earth-beaten tracks was utilized in the dry months. This system of khlong's and khlongsoi's joined with the public 'highway' of Khlong Saen Sap (see Figure 1), dug by government around the mid-19th century, to the south.

3. Khlong Kum with corridor hamlet settlement.

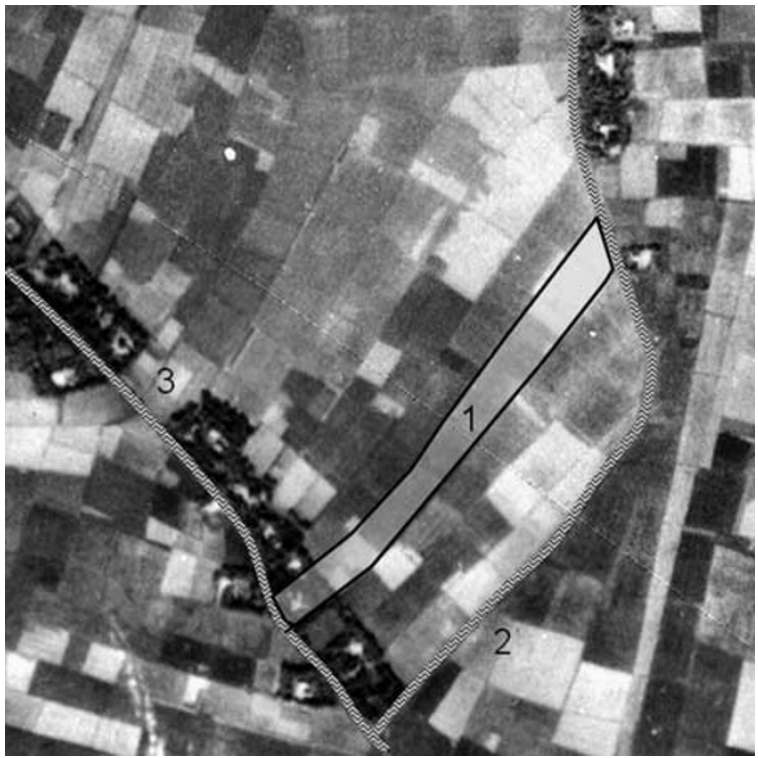

Figure 5. Agrarian pattern (1870s-1950s).

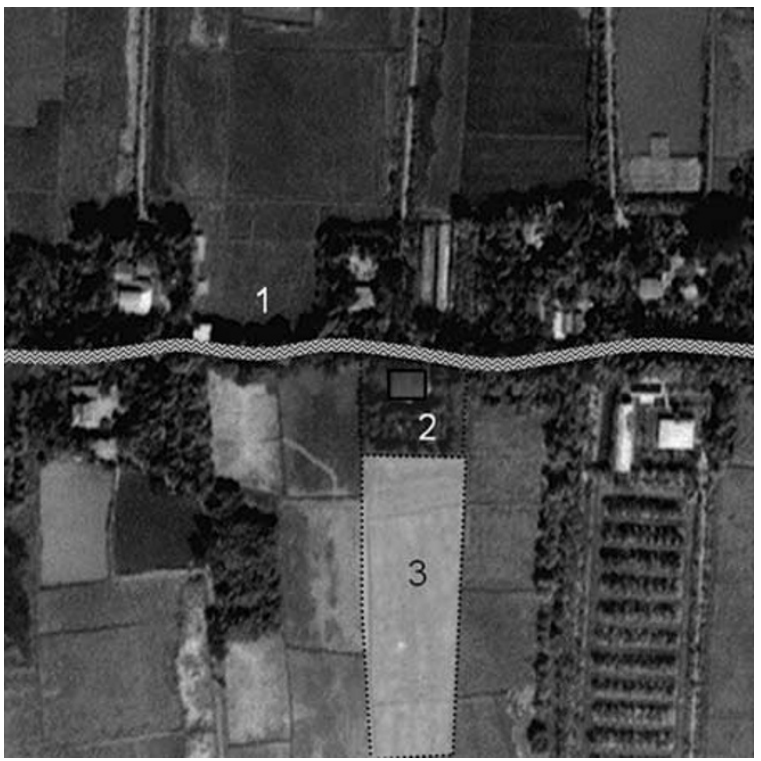

Figure 6. 'Water-based' Hamlet settlements (Jaijongrak, 1975).

Generated representation of hamlet settlements by the khlong's (Figure 6):

1. Khlong Lumjiek. Khlong's served multiple functions - water catchments during floods, irrigation, transportation networks, recreation spaces, etc.

2. Khlong-side house compound 'frequently surrounded by small irrigation canals $(k h u)$ leading into the main canal' (Kaufman, 1976, p. 20). Once established, strip villages build 


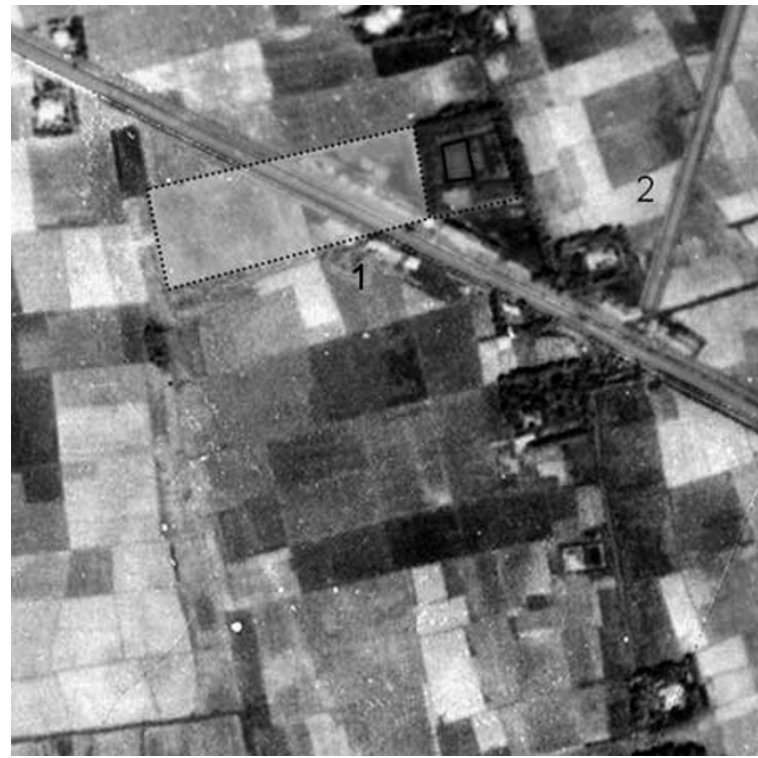

Figure 7. Thanon's.

temples/masjids that served as the focal point of community life - markets, rituals and festivities - within boating and walking distances.

3. Nha's (rice paddy fields).

Accessibility and urbanization (from the 1950s onwards)

Generated representation of the generic imposition of thanon's onto rural land (Figure 7):

1. Thanon Ramindra cut into hamlet north of Bangkuad, ignoring pre-existing patterns. The road was built to link the eastern towns and provinces with Bangkok, increasingly replacing Khlong Saen Sap's role with the land-based mode of transportation. The road quickly had an impact on local practices and villagers consciously re-oriented their lifestyles to the speed and convenience of the roads, further contributing land to build local feeders (soi's) to access the highway. They later reaped the economic benefits brought by the encroaching real-estate developments that came with the roads.

2. One of the earliest soi in the area linking to the local temple, Wat Kuborn.

Generated representation of private soi's branching off from the main road (Figure 8):

1. A hierarchy of soi's branching off of Ramindra highway, Sukhapibal 1 Road (constructed 1957,

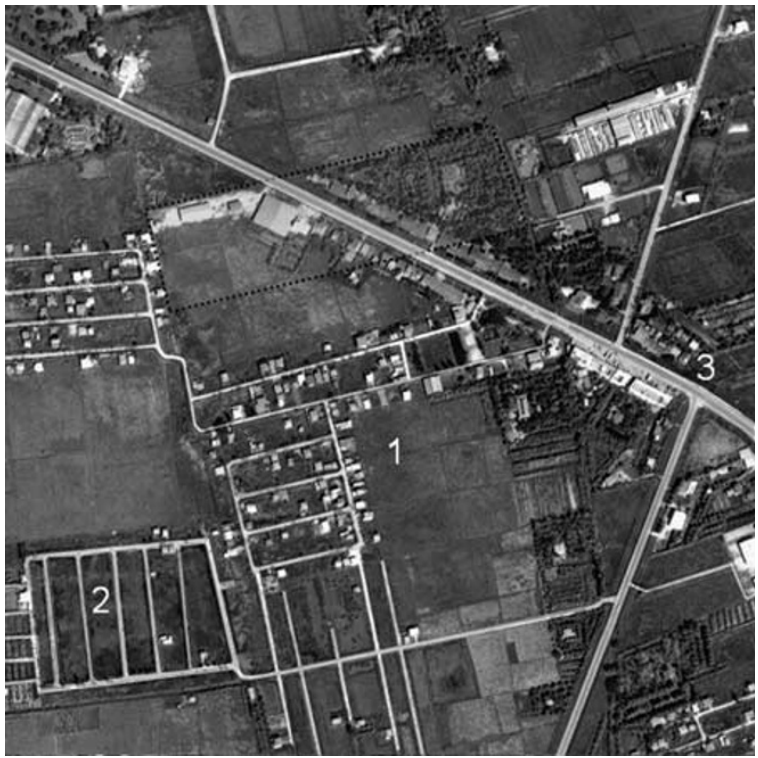

Figure 8. Soi's.

later renamed Nawamintr Road), the main soi's such as Soi Kuborn, fragmenting previous rural lands into various real-estate developments. Unlike the blunt imposition of main roads, the patterns of soi extensions are influenced/framed by agrarian orientations and patterns, as each landowner individually and varyingly participates in the piecemeal development of their rice paddies into Bangkok's suburb.

2. Early 'land development estates' (since the late 1950s) as differentiated from 'housing estates' that appeared in the urban fringe since the early 1970s (Durand-Lasserve, 1980, p. 2).

3. Kilo Paed intersection amalgamating into a local center.

Generated representation of the thanon's and soi's network combining to form the superblock. The transformation from agrarian to urban society begun little over half a century ago with the role reversal between khlong's and roads being complete (Figure 9):

1. The case superblock. Note how the new highways to the west and south, constructed in the 1990s, cut arbitrarily through the fine soi networks as well as through the land holdings and khlong's.

2. Open-space fragments, the result of both 'leapfrogging' suburbanization pattern and 


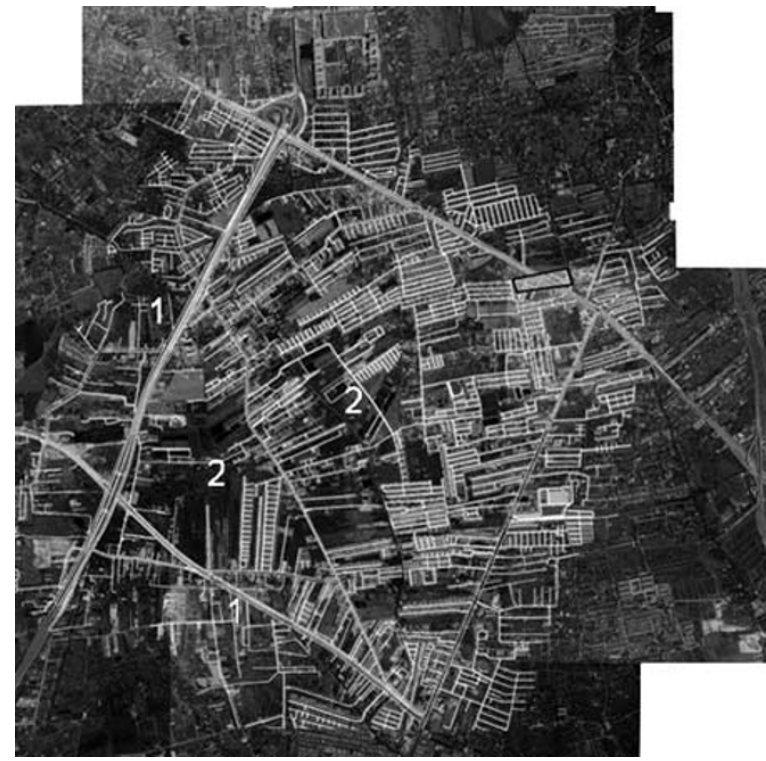

Figure 9. Superblocks: pattern of Bangkok's lateral expansion.

inaccessibility, are apparent throughout the site (dark gray areas within the superblock).

The superblock 'as is' is likened to a modern, automobile city imposed upon an agricultural village yet retaining its rural land subdivision patterns and replicating the characteristics of the village's khlong's typologies in the utilization of road surfaces (multifunctional utilization of soi surfaces for transport, commerce, recreation, etc.). What manifests is an incomplete superblock characterized by the prevalence of open-space fragments - whether the result of inaccessibility or 'leapfrogging' development of varying scales particularly in the superblock's center and scattered among densely settled areas near the main roads. The next section, 'Scenario I', projects the continuation of this pattern 20 years into the future.

\section{Scenario I: 'Unmediated change 2020' - existing patterns persist (weak or no intervention)}

In this scenario, the superblock matures (subjected to possibly two to three cycles of economic growth and recession). The urban fabric is well developed, similar to older blocks near the urban core, inheriting and propagating many problems of the contemporary inner city.

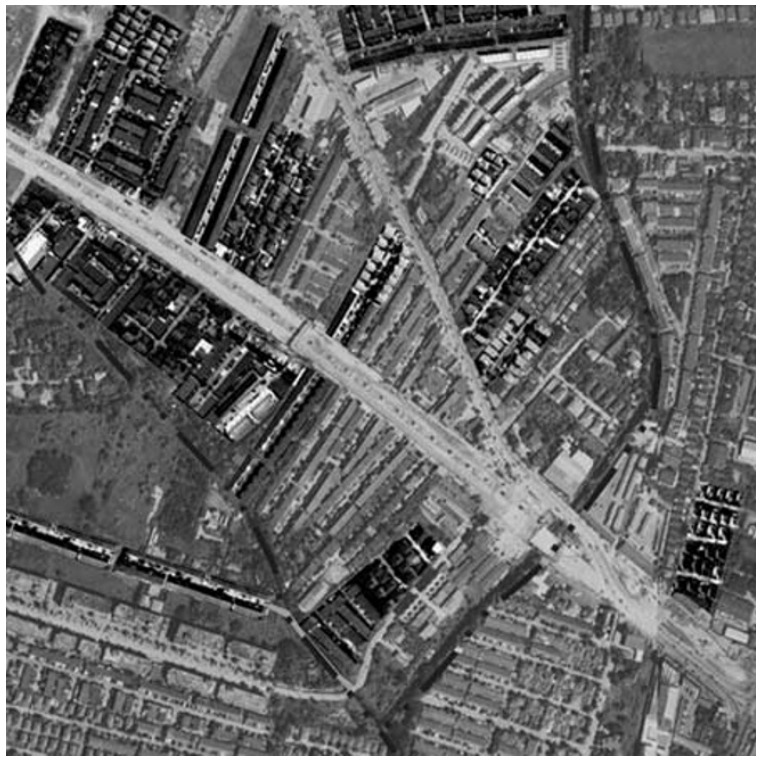

Figure 10. Pattern pre-human settlement: erased.

Bungkum district is projected to have a population growth rate of $2.2 \%$ per annum from 1997 to 2007 and $0.89 \%$ per annum from 2007 to $2017^{8}$ (DRTP, 2002, pp. 4-4). Extending the $0.89 \%$ per annum rate for an additional 3 years and would result superblock's population to be about 66,284 (an increase of 31\% from 2000 numbers).

The diagrams model the process of unmediated change, where the suburbanization/urbanization processes represented in the 'as is' diagrams continues basically unabated. Figures 10 model the erasure of the pre-settlement natural conditions and pre-urban rural settlement patterns by the city.

\section{Ecological, rural patterns 2020: fragmenting;} diminishing; transforming; disappearing

Generated scenario of the city's growth and intensification resulting in the erasure of preexisting ecological patterns physically, and thus also of the inhabitant's and their descendant's awareness of those patterns (Figure 10).

Generated scenario of the absence of agrarian use but rural patterns are still reflected in the physical patterns of soi's and real estate development. Khlong's, now lined with concrete embankments,

${ }^{8}$ From 1987 to 1997, Bungkum district had $11 \%$ annual population growth which was the highest in Bangkok. Reaching saturation point combined with increase in land prices, growth has since shifted to districts and provinces further out (DRTP, 2002, pp. 4-4). 


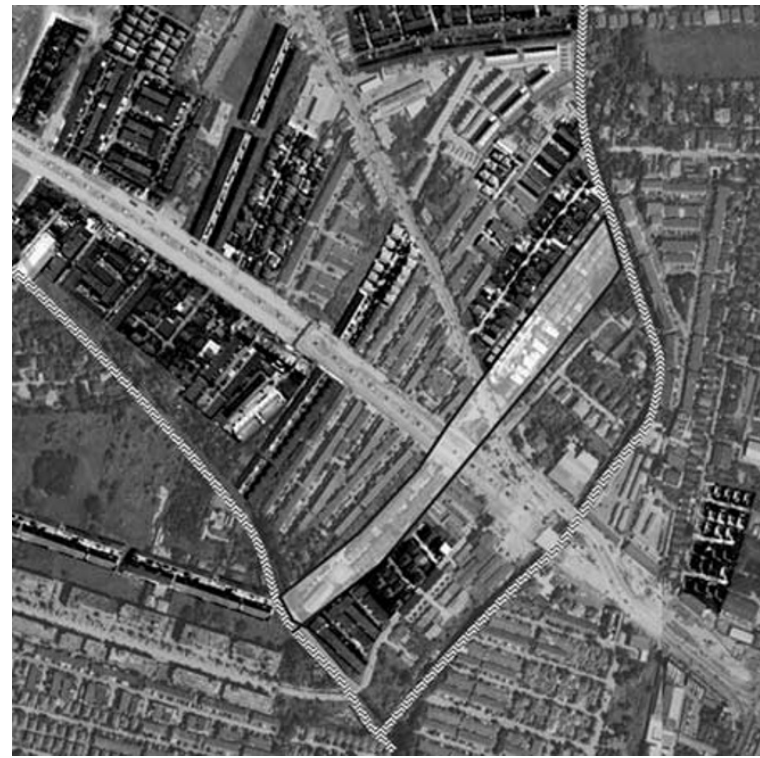

Figure 11. Agrarian pattern: framing suburbanization patterns.

efficiently functions as open sewerage and drainage system. The finer networks of khlongsoi's and khu's have long been filled up as their water catchments role has become redundant since large concrete dykes (doubling as highways) shield urban Bangkok from the seasonal floods, although subjecting surrounding predominantly rural lands outside the dykes to more severe inundations (Figure 11).

Generated scenario of former hamlet settlements encroached by the suburbs (Figure 12).

1. Former village settlements totally obscured by generations of newcomers brought in by roads and real-estate developments.

2. Persistence of 'undeveloped' land likely to be located in less accessible areas further off the main road system.

This unmediated scenario (Figure 13) continues the current localized hegemonic patterns of urbanization in Bangkok. Based on contemporary principles of sustainability (of early 2000s), this scenario has ventured far off-course. The superblock will be devoid of 'nature', crammed with built stocks that maintain a parasitical relationship with the outskirts. The public realm remains unattractive and uninspiring - hot and not people oriented unlike the private realms in the higher end-gated communities constructed since.

Under this model, the superblock, through the process of progressive intensification, has mimed

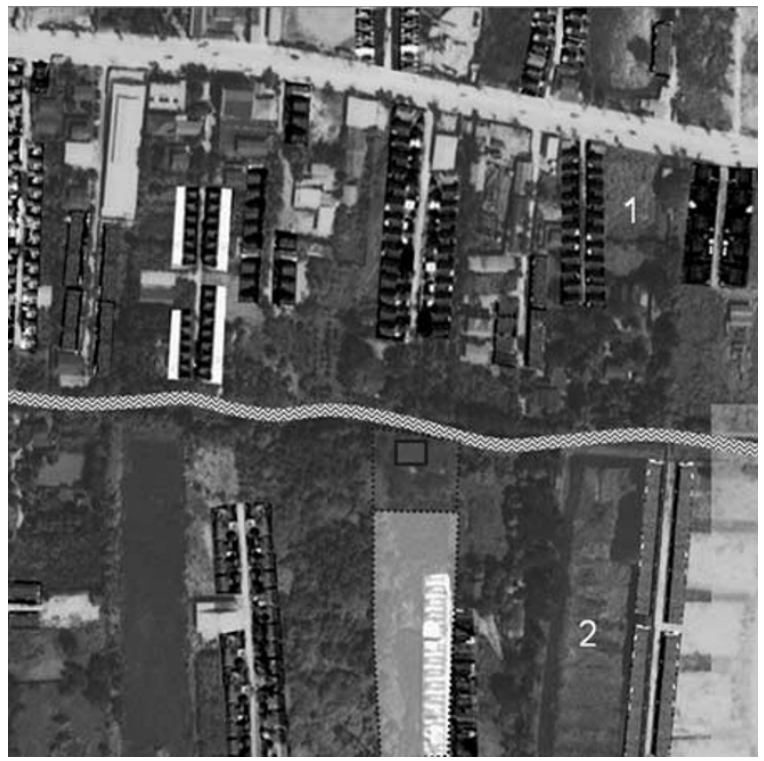

Figure 12. Hamlet settlements: fragmented and diminished.

the developments - forms of the inner city. However, the superblock and surrounds would not be as densely settled as urban growth would be dissipated further out into the cheaper lands of the exurbs and adjacent provinces (often subjected to different, uncoordinated regulations) and, due to the consequent compounded traffic congestion, be eventually served with rail masstransit. By that time, there is a likelihood of more local autonomy for the district and thus increased avenue for more locally responsive public developments (and even 'proper' public participation). For that reason, combined with improved tools and know-how of the planning agencies, there may be improvement in the public realm and the lives of the inhabitants particularly compared to the conditions of the inner city and the superblock 'as is' in 2000. But as mentioned, when assessed against the Model for Sustainability (Figure 2), the improvements, often through uncoordinated and incremental small-scale interventions, are relatively minor - as fundamental issues and ingredients are not addressed - and an alternative course, plotted in the next section, is desirable.

\section{Scenario II: 'Mediated change 2020 ' - negotiating towards 'sustainability' (generating possible 'answers')}

In this mediated change scenario, current patterns of urbanization are critically reassessed with the 


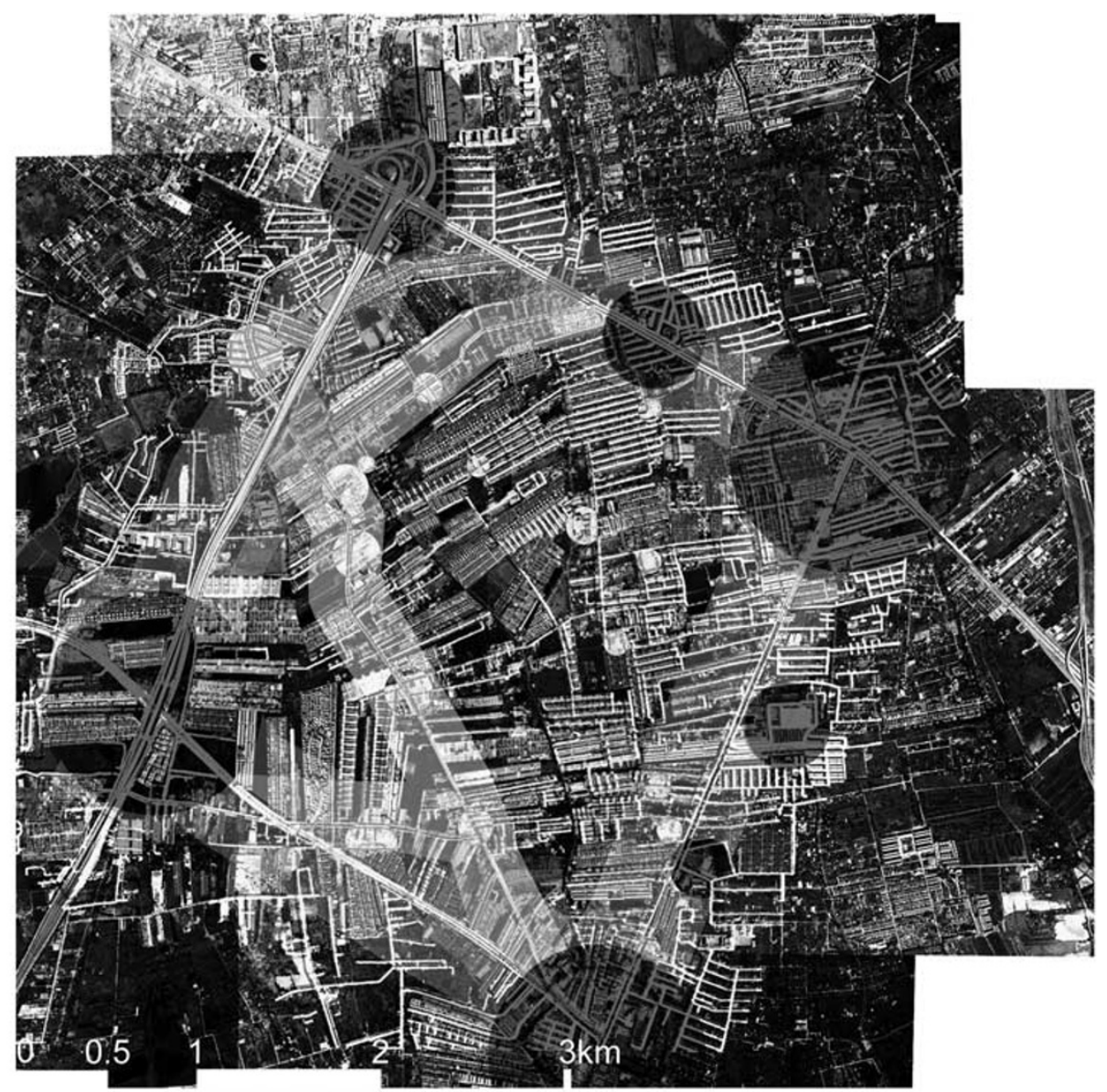

\section{Key Components*}

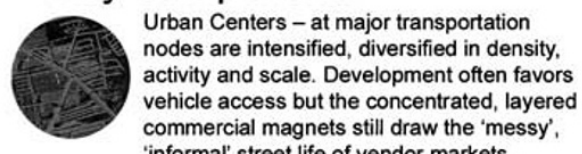
'informal' street life of vendor markets.

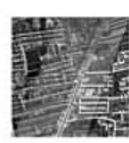

Urban Corridors - variedly infilled and intensified along main roads and corridors, particularly at nodal intersections with 'suburban corridors' and soi's. The

intermediate sections between nodes are infilled with activities favoring vehicle access.

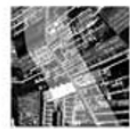

Suburban Corridors - intensified particularly at nodal intersections with 'urban corridors' forming sub-centers and at intersections with

soi feeders forming smaller scale centers serving existing and new suburbanites in new infill developments.

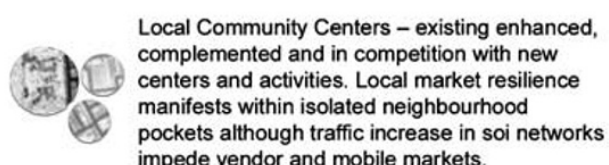
impede vendor and mobile markets.

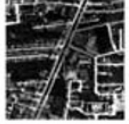

Soi's - rationalized for vehicle traffic with little or no accommodation of pedestrian, bicycle and vendor movements. Soi's within subdivisions

and dead-ends accommodate community recreation functions and temporal markets.

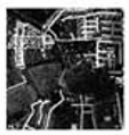

Khlong's - engineered into concrete channels for maximized drainage, water treatment efficiency. Water quality improves with functioning of

sewerage treatment facilities. Isolated attempts to reorient and retrofit recreational activities by the cleaner khlong's which is otherwise obscured within intensified urban fabric.

* Urban intervention, improvement occurs uncoordinated and incrementally on one or part of a component,

integrated actions are rare.

Figure 13. The unmediated change superblock 'model'.

capability to retrofit those processes to guide suburbanization towards the goals of sustainability. This also encompasses the transformation of perceptions of khlong's and of 'nature' itself. The main tools for implementation would be land readjustment/reorganization - already earmarked to resolve Bangkok's and Thailand's hitherto laissez faire land developments - and more public realm-oriented regulations for both public and private developments. 


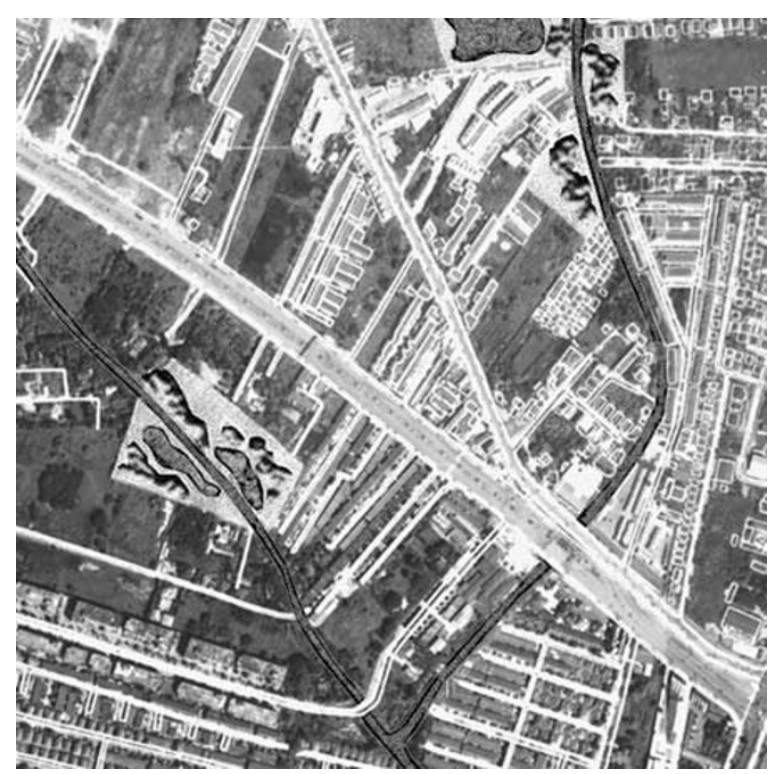

Figure 14. Pattern pre-human settlement: reinvoking memories.

Diagrams model the process of suburbanization of the superblock starting from the conditions 'as is' and mitigated by the 'model for sustainability' (Figure 2), implementing the 'design objectives' stated earlier. Figures 14 and 15 illustrate how 'commons' of nature and agriculture can be reintroduced, in evolved forms, and become an integrated function within the suburban fabric.

Ecological, rural patterns 2020: clustering; expanding; consolidating; re-appearing

The 'Commons' 1 (Figure 14)

- Reversion back to pre-existing forms is not mandatory (Hough, 1995, p. 30)

- 'New nature' - multipurpose, both non-utilitarian and practical (Dearden, 2002, p. 391) (eg flood mitigation, water/air cleansing systems, ground water recharge, etc) to be woven into and integrated with urban movement networks.

The 'Commons' 2 (Figure 15)

- Revived 'new agriculture' functioning in symbiosis with 'new nature'.

- The urban agriculture patches serve multiple socio-economic objectives - as subsistence existence and supplementary income for urban poor and as near-source fresh food supply for urban markets (formalizing what is already informally practiced by the urban poor).

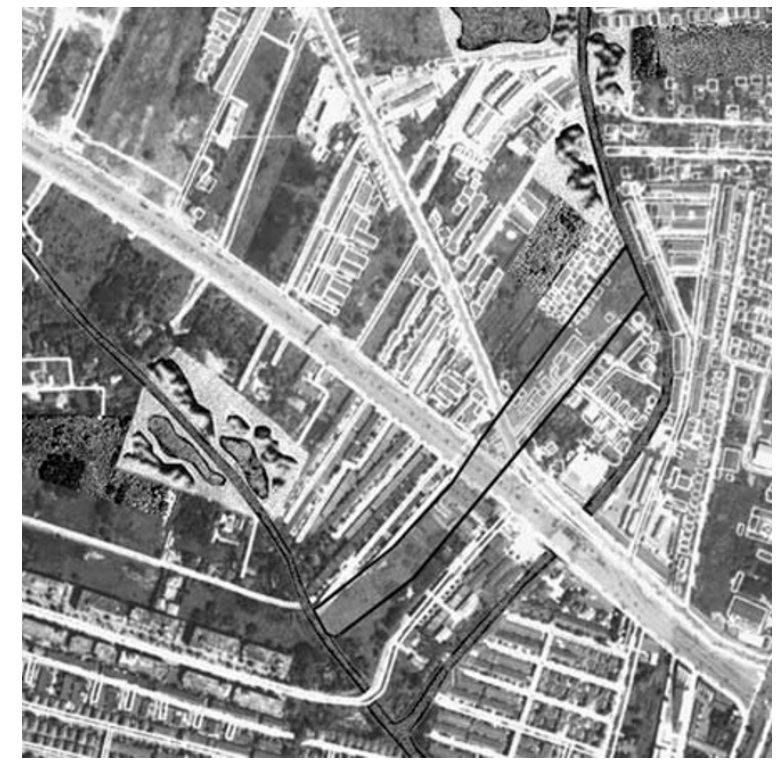

Figure 15. Agrarian pattern: re-introduced.

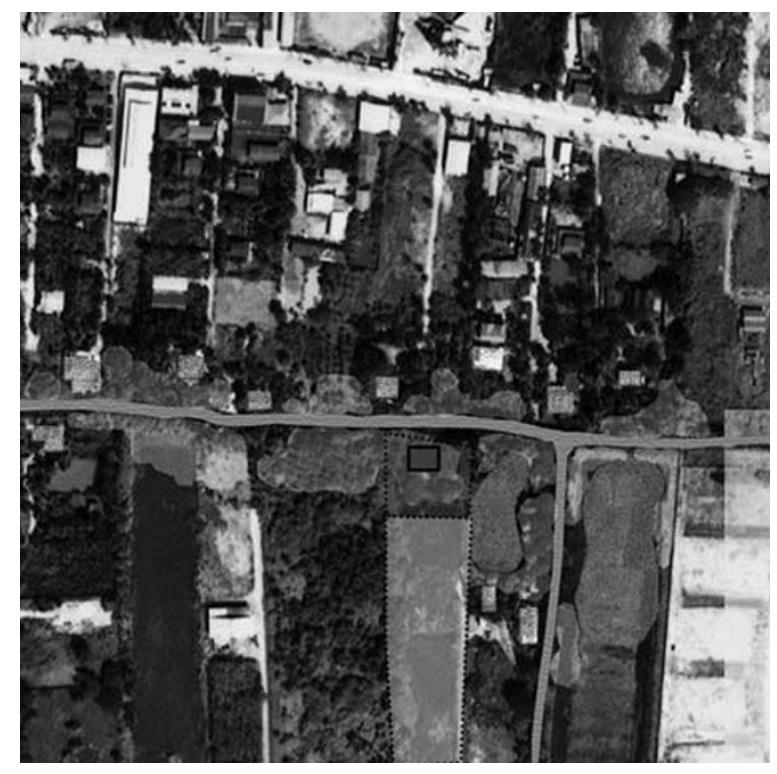

Figure 16. Hamlet settlements: re-orientation of suburbs to khlong's.

Revival of khlong's life - settlements, open spaces, circulation. On the fundamental level, it readdresses the (forgotten) intrinsic cultural characteristics that arose from the local topographic, natural contexts and make the most of the khlong's central role in rejuvenating suburban Bangkok's urban landscapes (Figure 16).

The 'mediated change' scenario focuses on two main issues; the retrofitting and introduction of 


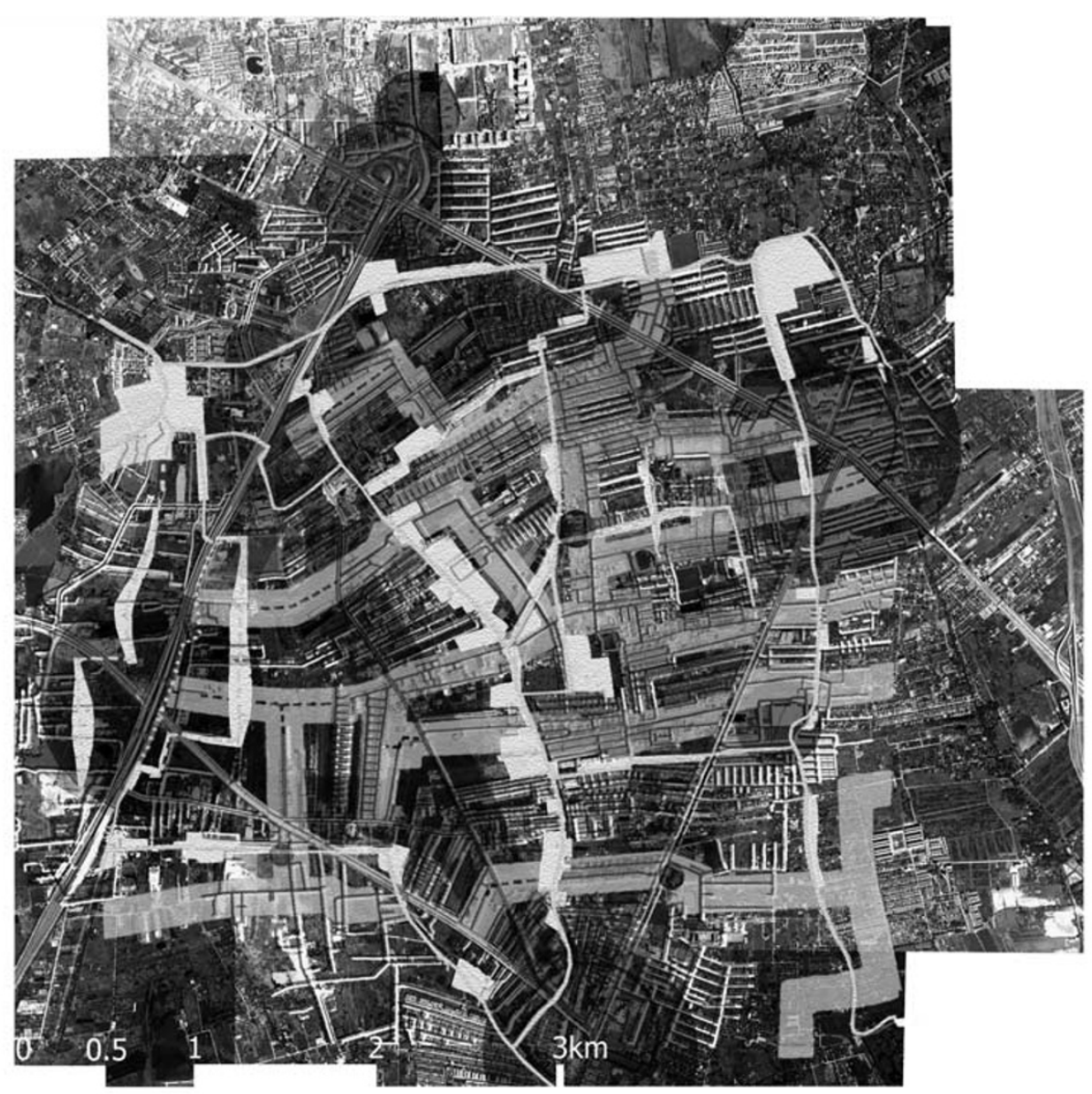

\section{Key Components*}

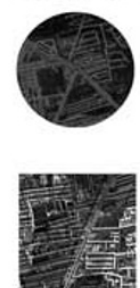

Urban Centers - concentrations of mixed-use, high-density nodes of retail, commercialresidential functions. Major transportation interchanges.

Urban Corridors - concentrations of mixed-use, high-density retail, commercial-residential functions along highways and major roads (6-8 lanes, wide footpath) served by rapid masstransit system (rail, bus). Can combine recreational/sports activities (as under raised expressways).

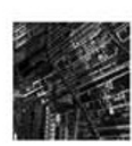

Suburban Corridor - concentrations of mixed-use medium to high-density commercial-residential functions along secondary roads (4-6 lanes, wide footpaths) linking across superblocks. Serviced by public buses, local privately operated transportation.

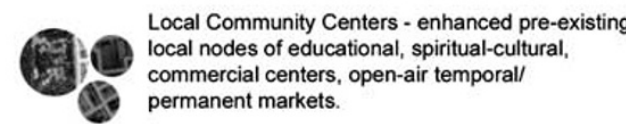
permanent markets

Neighbourhood "Ped-sheds" - concentrations of mixed-use low to medium-density commercialresidential functions along main soi's (2 lanes, widened or with "verandahways") that link across superblocks. Serviced by local privately operated transportation (songtaew's, motorcycle-taxis). Easily accessible via pedestrian/bicycle/vendor friendly secondary and "woonerf" soi's.

Green and Blue Corridors/Mesh of mixed-use flood mitigation/waste treatment/recreational/rural/ ecological functions along pre-existing and

resusitated khlong's. Multiple-scaled depending

on available plots. Accessible via pedestrian/ bicycle/vendor ways (motorcycles allowed at very low speeds) - and possibly boats.

- Intensified planning/design/public participation required at component overlaps which occurs in varying circumstances within and across superblocks.

Figure 17. The mediated change 'model' for the Bangkok superblock: mitigating the zoning mindset (which does not reflect the diverse uses on-ground reality), reorganizing the key components and encouraging dynamic overlaps.

integrated multipurpose open spaces of nature, green and blue stocks in the suburban fabric and improvement in the urban environment, particularly in the public realm shared by all citizens of the superblock. The 'model for the Bangkok superblock' (Figure 17) is the culmination of the alternative scenario process synthesizing the superblock's local ingredients with the principles 
of sustainability. Consistent with the spirit of sustainability, the model is not prescriptive but proposes a flexible framework that encourages participation and input from multiple stakeholders at differing scales. The design speculation in the next section is conceived with the same intention and serves to further clarify the objectives of the proposed heuristic process.

\section{Design speculation, translation of 'superblock model'}

From the 'generic' model for a more sustainable superblock (Figure 17), a design translation process of the model is proposed, beginning with the first set of diagrams that map the case superblock's evolution (Figures 18) and, in layers, component breakdown of 'as is' (Figures 21). As the design process was undertaken at the transition period between the Bangkok masterplans of 1999 and of 2004, the next two diagrams illustrate part of the masterplans corresponding with the case site, also commenting on the changes made from the 1999 (Figure 25) to the 2004 (Figure 26) plans. The plans reflect the formal and informal (and in-betweens) decision-making process since the edict that cleared the natural lands for rice farming in the late-19th century and Bangkok's first official masterplan of 1992.

The subsequent set of diagrams illustrate the broad design decision-making process beginning with the identification of the unbuilt open-space fragments (Figure 27), the discernment of plot patterns (Figure 28) and, based on those openspace fragments and plot patterns, a land readjustment into 'developmental plots' and 'commons' (Figure 29). Based on the land readjustment plan, the last two plans of 'commons development strategy' (Figure 30), further speculating the design/planning resolution of the commons, and '(sub)urban development strategy', speculating the design/planning resolution of the developmental plots, (Figure 31 ) are projected.

\section{The superblock: evolution}

Formal decision (Figure 18):

- Late-19th century edict to open new lands for paddies when rice became the main Siamese export. Earliest 'sprawl' of rice paddies with

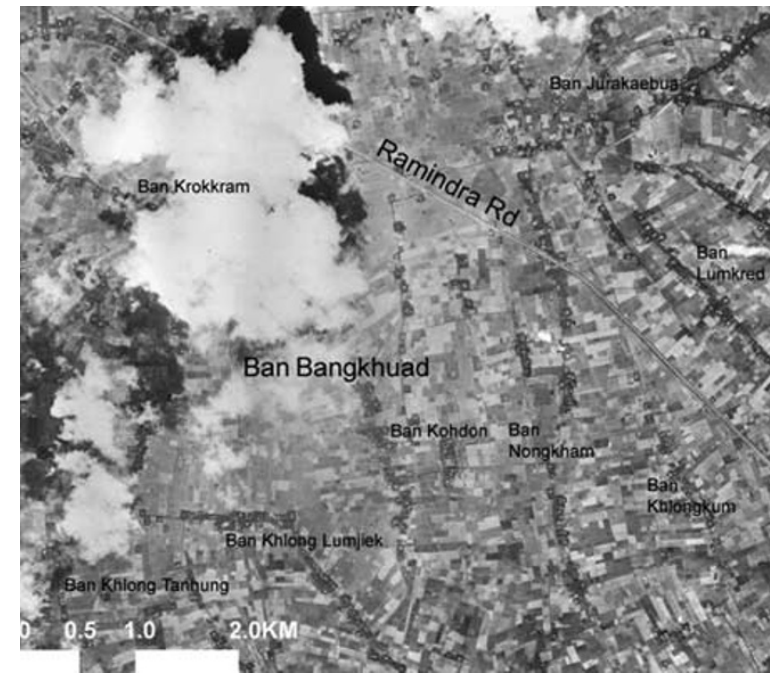

Figure 18. Bangkhuad (aerial photograph 1952; names of surrounding settlements from BMA and JICA (1988) survey map).

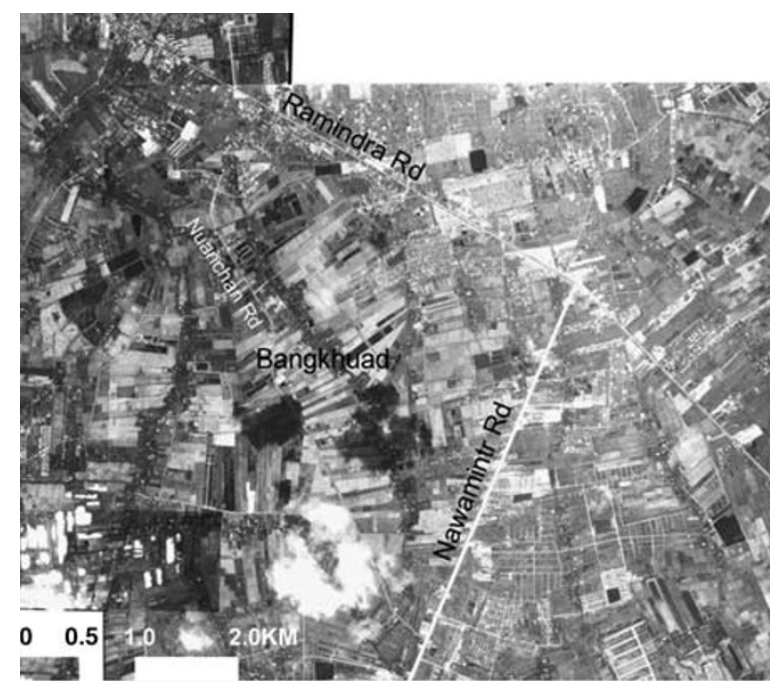

Figure 19. Bangkuad (aerial photograph 1981).

settlement corridors along $k$ hlong's into natural lands.

- Mid-20th century construction of Ramindra Rd. to link to eastern towns and provinces beginning the transformation from 'water-based' to 'land-based' culture of settlements to adopt Jumsai's (1997) terminologies.

Formal decision (Figure 19):

- Construction of Nawamintr Rd (formerly Sukhapibal $1 \mathrm{Rd})$. 


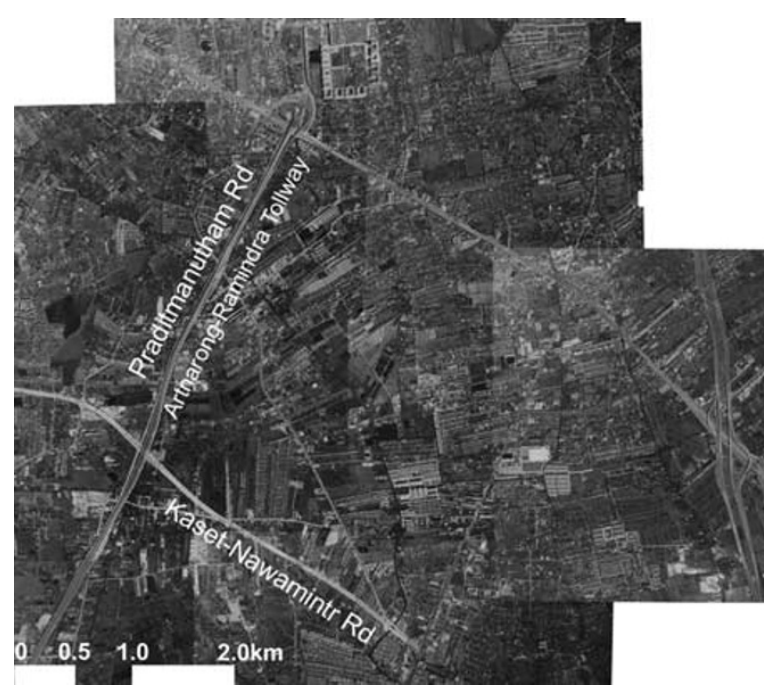

Figure 20. Aerial photograph 2000.

- Speculators and developers buy into existing and former agricultural lands to subdivide and sell.

Informal decision: Locals build soi's to connect their properties to the main roads. Conflict between the water and land as roads and soi's literally eat their way into and fragmenting the existing and former rice paddies. Transformation from agricultural economy to Bangkok's dormitory suburb.

Formal decision (Figure 20): Build new roads (Kaset-Nawamintr and Praditmanutham Rd.) and toll-ways (Artnarong-Ramindra over Praditmanutham); widen existing roads to accommodate increased population as a result of economic and real estate boom of the mid-1980s to mid1990s. New roads open up once inaccessible lands (open-space fragments) to development.

Informal decisions: At finest scales, vendor and weekly markets, recreational appropriation of soi's and 'slabs'; squatter settlements along khlong's.

The superblock: existing conditions - component breakdown

Formal decisions (Figure 21):

- Late-19th century decision to accentuate for transportation, drainage and irrigation as well as for recreation.

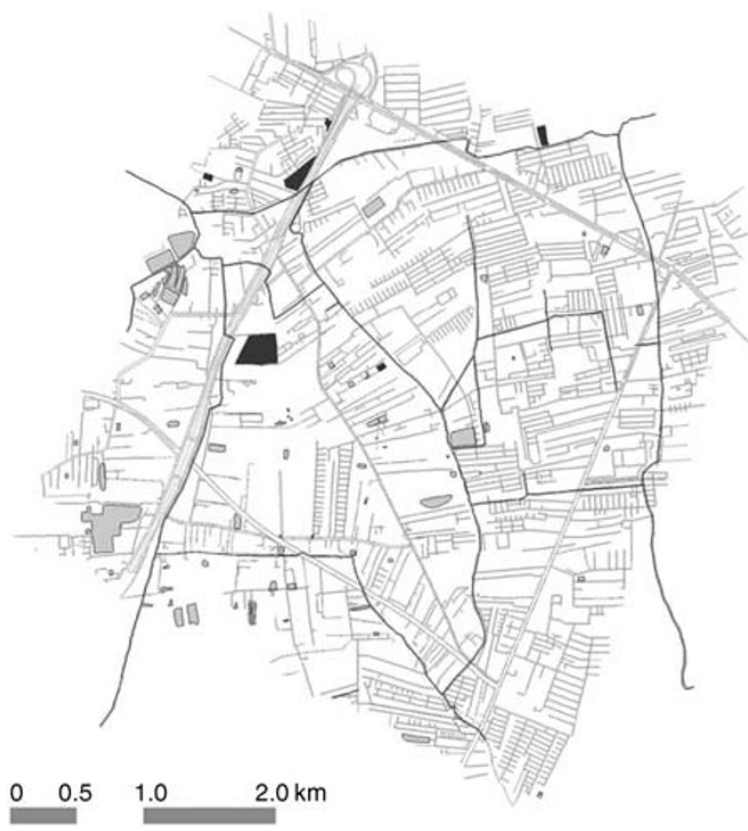

Figure 21. Existing Khlong's and water bodies 2001 remnants of pre-existing natural system.

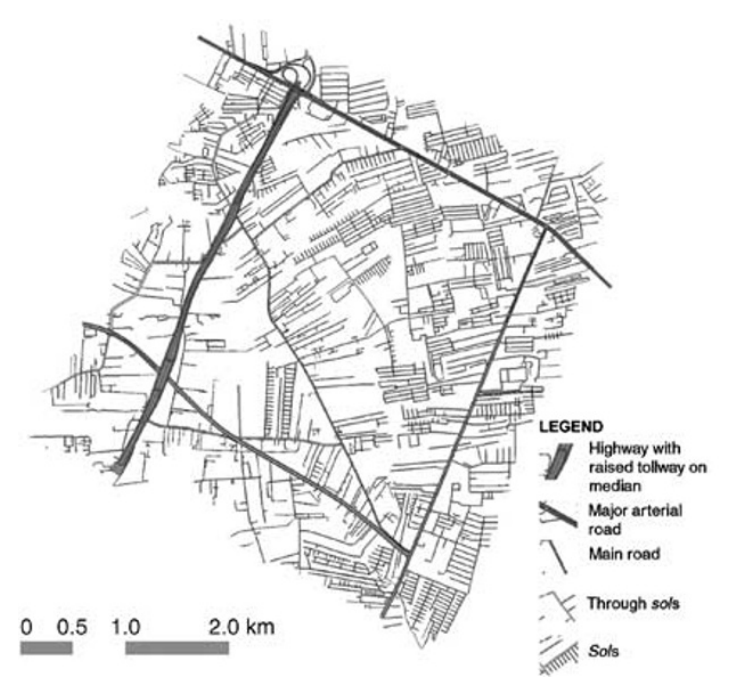

Figure 22. Road surfaces 2001.

- Mid-20th century onwards filled in to build roads and for real estate subdivisions. Utilized as drainage and open sewer.

Formal decisions (Figure 22):

- Government decision from mid-20th century: Imposing main roads on pre-existing ecological and agricultural patterns. Homogeneous use.

- Developer and local decisions: build soi's that follow landownership patterns. Multiple uses 


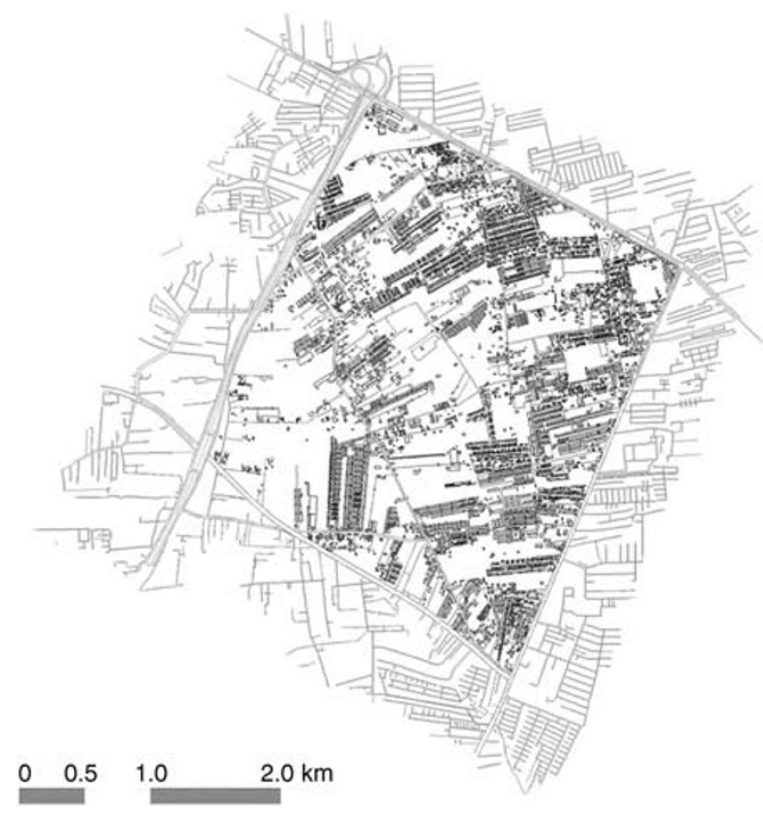

Figure 23. Building footprint 2001.

for commercial and recreational purposes due to almost no formal provision of open spaces by both government and developers.

Formal decisions (Figure 23):

Developer and local decisions: Intensification along roads and main soi's; fill-in with subdivisions further off from road and characterized by undeveloped open-space fragments deep into the superblock.

The 'white' unproductive (and unclassified on plan) and 'green' 'rural and agriculture' forms the 'open-space fragments'. Laissez-faire - highly mixed use. No official recording of informal uses (Figure 24).

\section{The superblock: official decision-making 'models' (Figures 25-26)}

Consistent with the paper's proposal is the superblock perimeter highways to be augmented with rail mass-transit systems. Follow after private developments (which in turn follow public road developments). Lack finer scale plans and visions, lack public open spaces for both social and ecological functions. Mass-transit systems planned principally to address traffic problems rather than as part of comprehensive plans with urban design visions (Figure 25).

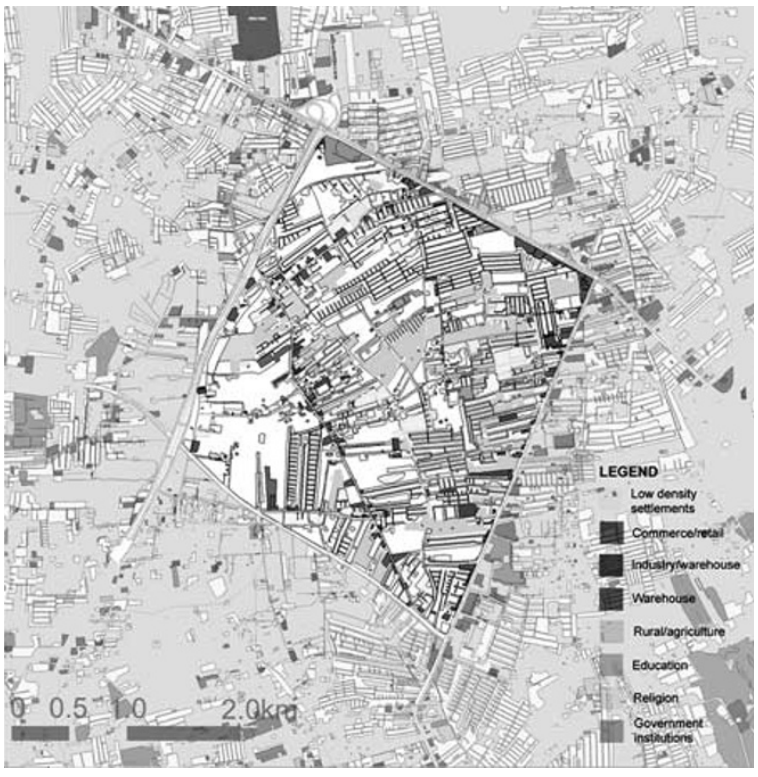

Figure 24. Land-use plan.

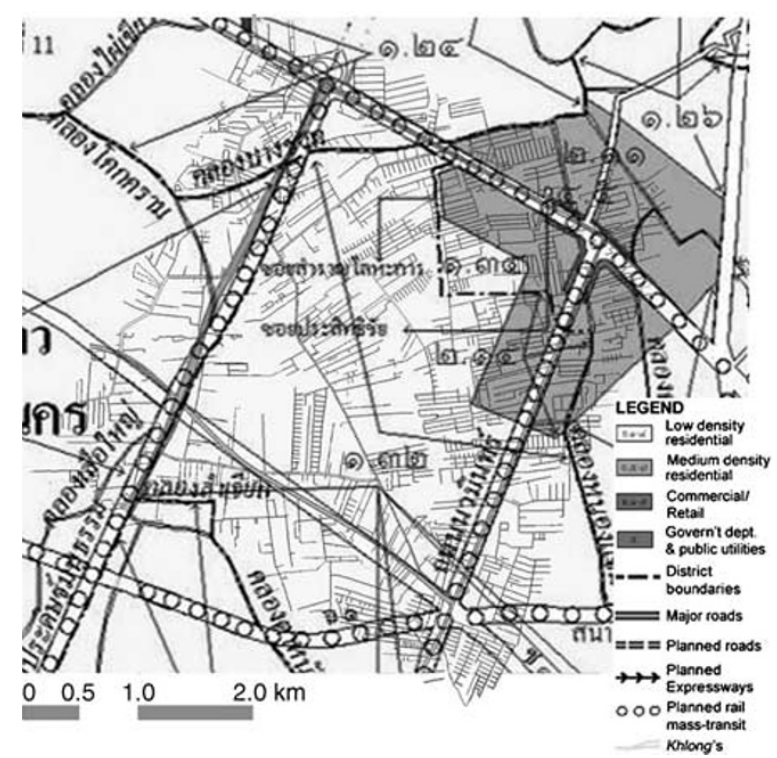

Figure 25. Bangkok second Masterplan 1999.

Rail mass-transit system now only runs on the south perimeter of the superblock - with raised expressways to cut through the southern portion of case superblock and also continue north from the existing Artnarong-Ramindra route. Proposed east-west roads to slice through superblocks south and east of the case site. Increased commercial and retail zonings after actual onground expansion (Figure 26). 


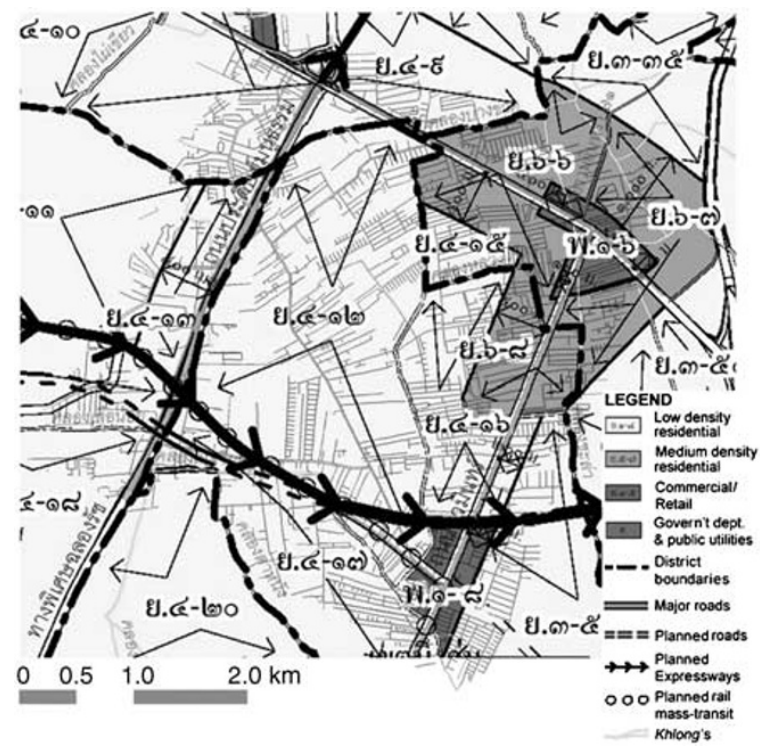

Figure 26. Bangkok third 5-year masterplan (originally to be effective July 2004 but has since been delayed).

\section{Superblock readjustment: finer scale intervention (Figures 27-29)}

Within the total area of the site superblock (bounded by highways) of $\sim 8.97 \mathrm{~km}^{2}$, $\sim 0.77 \mathrm{~km}^{2} \quad\left(\sim 481.28 \mathrm{rai}^{\prime} \mathrm{s}^{9}\right)$ are designated as 'commons' that are concentrated along pre-existing khlong's (cheaper but ecologically significant lands) while there are $\sim 2.32 \mathrm{~km}^{2}$ (1452.18 rai's) of 'development plots' with access to the commons much like the agrarian pattern of khlong's and long strips of sen's (Figure 5). Finer scaled strategies are then planned/designed for both 'commons' and 'developmental plots' illustrated in Figures 30 and 31, respectively.

\section{Superblock readjustment (Figures 30 and 31)}

\section{Discussion: superblock readjustment}

The aim of the 1999 masterplan was to achieve $2 \mathrm{~m}^{2}$ of urban park area per capita in 5 years (which by 2004 - had not been met) and in the long term to reach $10 \mathrm{~m}^{2} /$ person (BMA, 1999a, pp. 6-32). Through the design, retrofitting and readjustment process, approximately $0.77 \mathrm{~km}^{2}$ of 'commons' has

\footnotetext{
${ }^{9}$ The rai is the commonly used Thai unit of measurement for land area and is equal to $1600 \mathrm{~m}^{2}$ or 0.16 ha. All measurements are approximates.
}

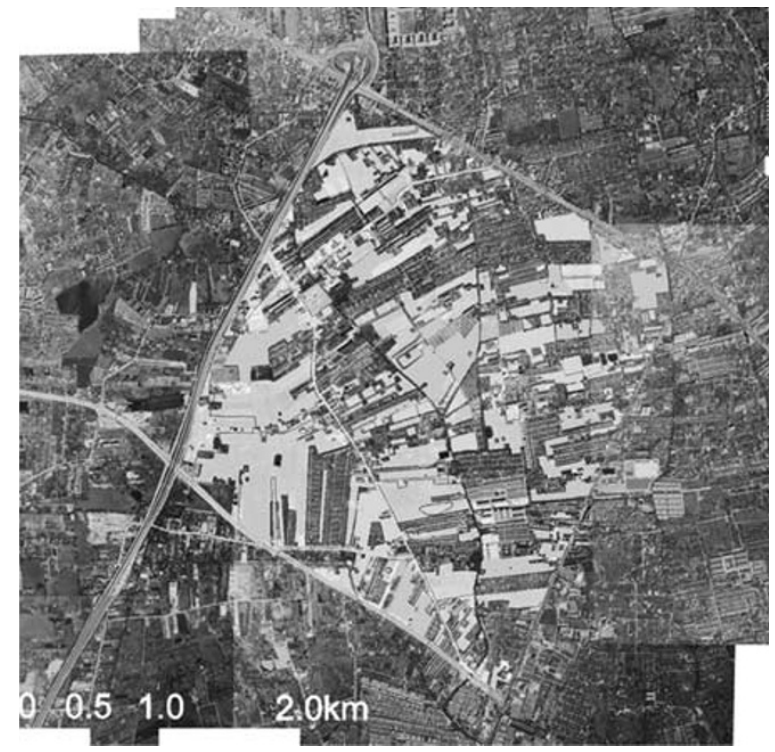

Figure 27. Intervention focused and proposed on unbuilt open-space fragments determined from aerial photograph and photogrammetry surveys.

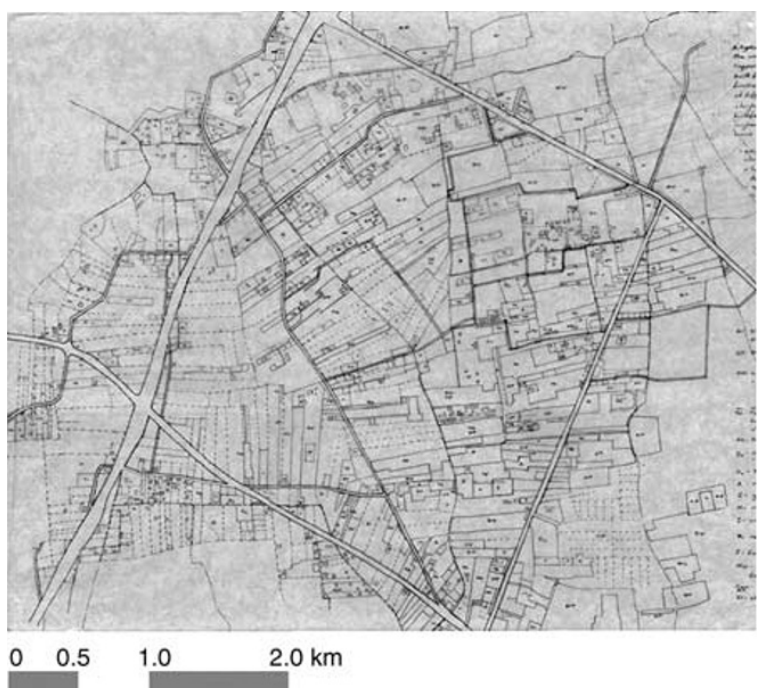

Figure 28. Plot patterns discerned from aerial photograph and pre-existing agrarian land patterns - roughing out boundaries where possible (working within the limit of not having land-ownership plan).

been designated within the case superblock, which amounts to $8.9 \%$ of the total land area (Figure 29). Thus, the superblock would have an estimated $11.62 \mathrm{~m}^{2} /$ person of public commons, exceeding BMA's official long-term objective by $16.2 \%$.

In the scenario that the superblock absorbs a higher population and reaches the inner city density of 15, 905 people $/ \mathrm{km}^{2}$ (BMA, 2001a, 


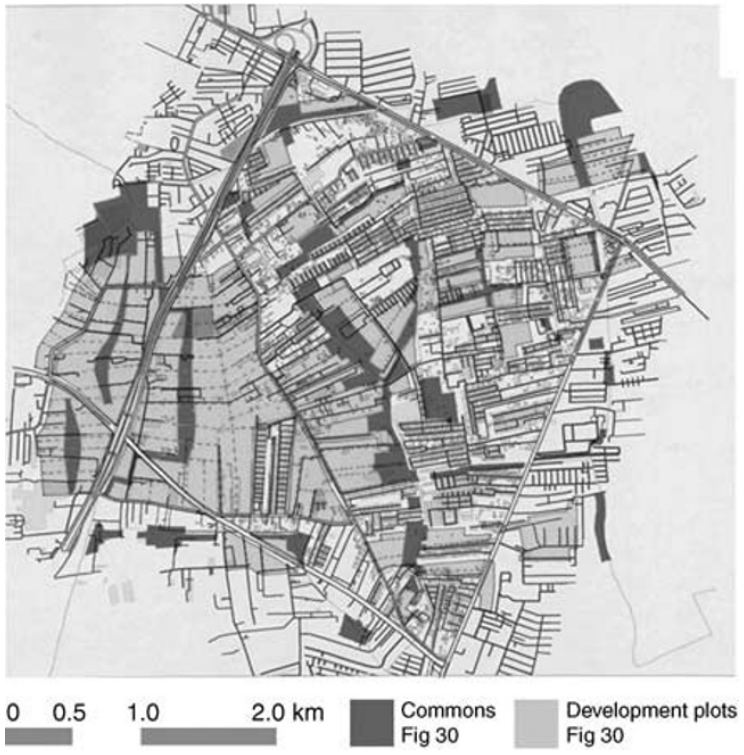

Figure 29. Based on design objectives set out in section 4 and official population projections, 'land readjustment' into 'commons' and 'developmental plots'.

pp. c2-7), the number would be $5.34 \mathrm{~m}^{2} /$ person of public commons. This population increase of over 90000 people within the site superblock is achievable projecting the higher ends of dwelling units/hectare for the development plots (Figure 31) based on Ellis' 'Residential Density

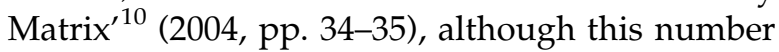
is calculated based on the Bungkum's 2000 average of three person per household ((BMA, 2001b, p. 2). These numbers, whether 11.62 or $5.34 \mathrm{~m}^{2} /$ person, have not included the 'commons' within each private development and also the recreational activity spaces provided by the now formalized and integrated woonerf ${ }^{11}$ soi's and recreational slabs network. In the long term, these private commons within each individual 'development block $^{12}$ would be integrated with the public common system and allow public access.

\footnotetext{
10‘3 Story Front Loaded Row Houses’ are categorized as low density (which corresponds more closely with Bangkok's categorization) whereas Ellis classified these as medium density.

${ }^{11}$ Dutch 'woonerf' streets - where 'distinctions between street and sidewalk are eliminated' and 'cars share the street with people and gardens' (Spirn, 1984, pp. 69-70). While the woonerf was invented, the soi's simply evolved.

${ }^{12}$ The 'development blocks' are to be mostly privately developed with clear guidelines and regulations for sustainability at finer site and building scales (which is not the scale that this paper addresses).
}

An increase in and diversification, categorization and formalization of typologies of water bodies serving multiple functions is also proposed within both the commons and the privately developed plots. ${ }^{13}$ These water bodies are linked with urban residential areas and activity centers through the various typologies of 'intermediate spaces' (Figures 30,31 ): the private commons regulated for the development plots; the existing religious and education centers; the intersections of commons and the various hierarchies of thanon's and soi's; pedestrian/bicycle/vendor-friendly woonerf soi's, etc. These spaces are planned/designed to enhance the inhabitant's quality of life; to retrofit the intertwined urban and natural processes in their everyday lives; and also to engage the inhabitants with the planning/designing, development processes - particularly at the neighborhood, community scales of the intermediate spaces as the aim of achieving sustainability is not limited to simply increasing and improving recreational amenities.

The plan is thus a critique of the large-scale masterplan imposed on Bangkok, which, despite their many clear merits and good intentions, often ignore the processes and realities on ground. The imposition of a large undifferentiated swath of color-coded zones also contain inherent inequalities that leads to conflicts - land owners and developers in the rural conservation and flood drainage protection zones argue for more diverse (urban oriented) utilization of their lands (Prachachat Turakij, 2004). In fact, the construction of dykes around the built-up area of Bangkok has only served to exacerbate this inequality favoring 'development' and the city - protecting urban Bangkok from both sudden and seasonal floods but sacrificing the surrounds, often rural lands, to more acute and prolonged inundations (Kemgumnerd, 2002).

As the whole pre-urban landscape once served as floodplains, it is proposed that the ecological pattern be revived and the built-up areas must share drainage and water catchment responsibility - thus the key roles of water bodies of khlong's and various ponds and the need for their increase.

\footnotetext{
${ }^{13}$ If existing ponds, the majority of which are currently inactive in flood mitigation, are also integrated with existing and proposed khlong's and ponds network, an increase of almost $300 \%$ in water body area would be achieved in the commons development strategy.
} 


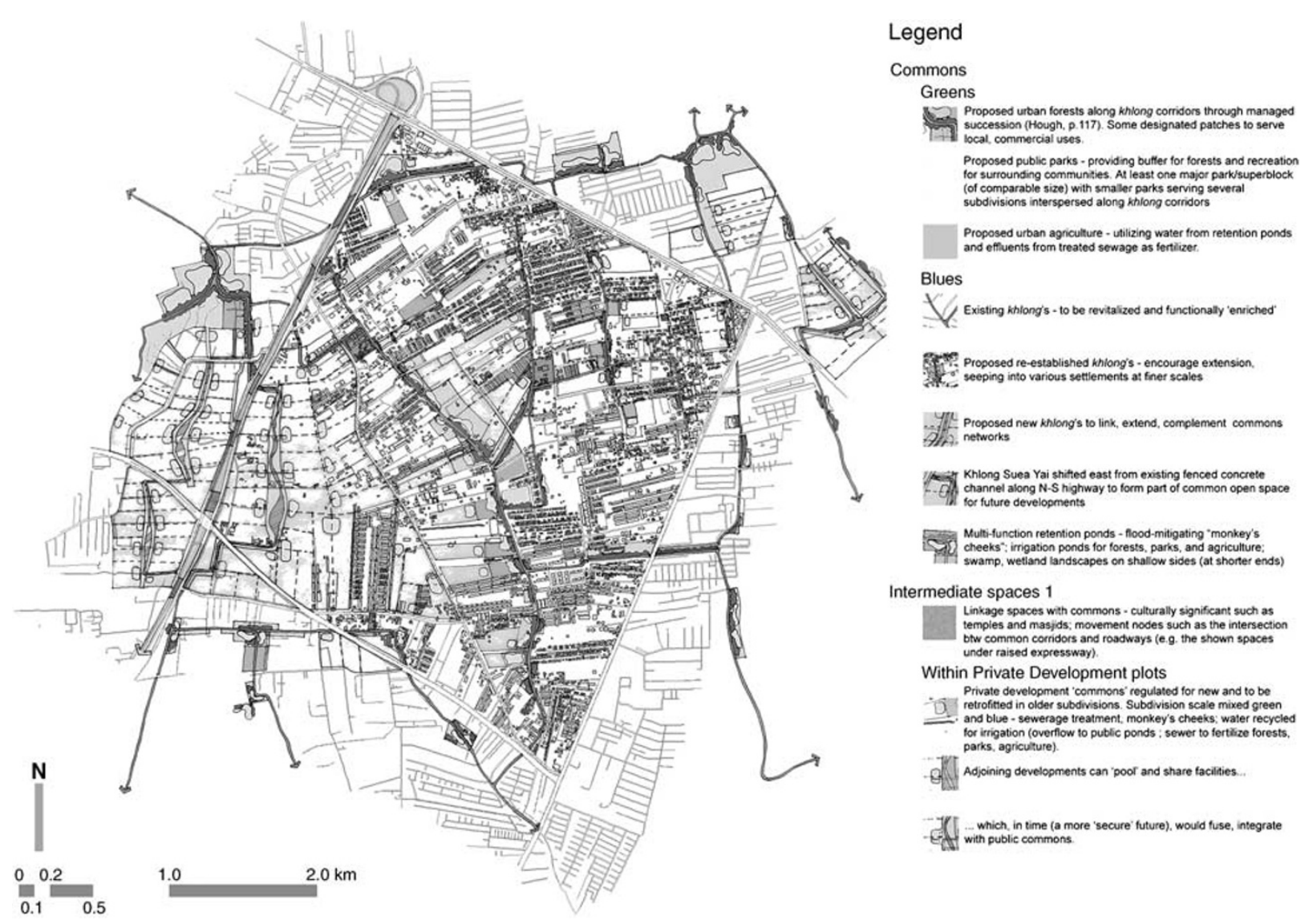

Figure 30. Commons development strategy.

It also calls for the creation of agricultural lands, serving both economic and social purposes, functioning in close relationship with the green and blue stocks integral to the urbanization process. The commons network, 'new' interlinked open spaces, serves multiple functions and purposes compared to the typical urban parks and could through routine engagements in time be perceived by urban inhabitants as an integral part of the city. The key here is diversity functional, social and ecological-rather-than the homogenizing tendencies of the city further encouraged by the zoning approach of the masterplans.

Through this approach of concentrating on the processional realities, the problem of sprawl and its adverse impacts can be more effectively preempted. Urban readjustment is not limited to the physical elements but must also be applied on the process - such as of sprawl, which ignores physical boundaries. The allocation of land for the 'commons' and also having the private sectors contribute by adding green and blue stocks (as well as public thoroughfares) and integrate them with their developments is insufficient. Sprawl is closely aligned to market forces that must be addressed through decision-making on the level of the masterplan coordinated with finer local plans and its enforcement mechanisms. The strategically planned organization of Bangkok into a polycentric city must be implemented concurrently, consistent with the 'decentralizedconcentration' model, which also aims to create local centers of employment (Robinson, 1995; DTCP, 1999; Kaothien and Webster, 2000).

\section{Conclusion}

The design process described here illustrates that by critically applying the generic tenets of 'sustainability', a marked improvement in the quality and diversity of the urban environment, focused on open spaces, can potentially be achieved. This proposition does not simply impose more sustainable physical forms per se but rather translates the normative qualities of 


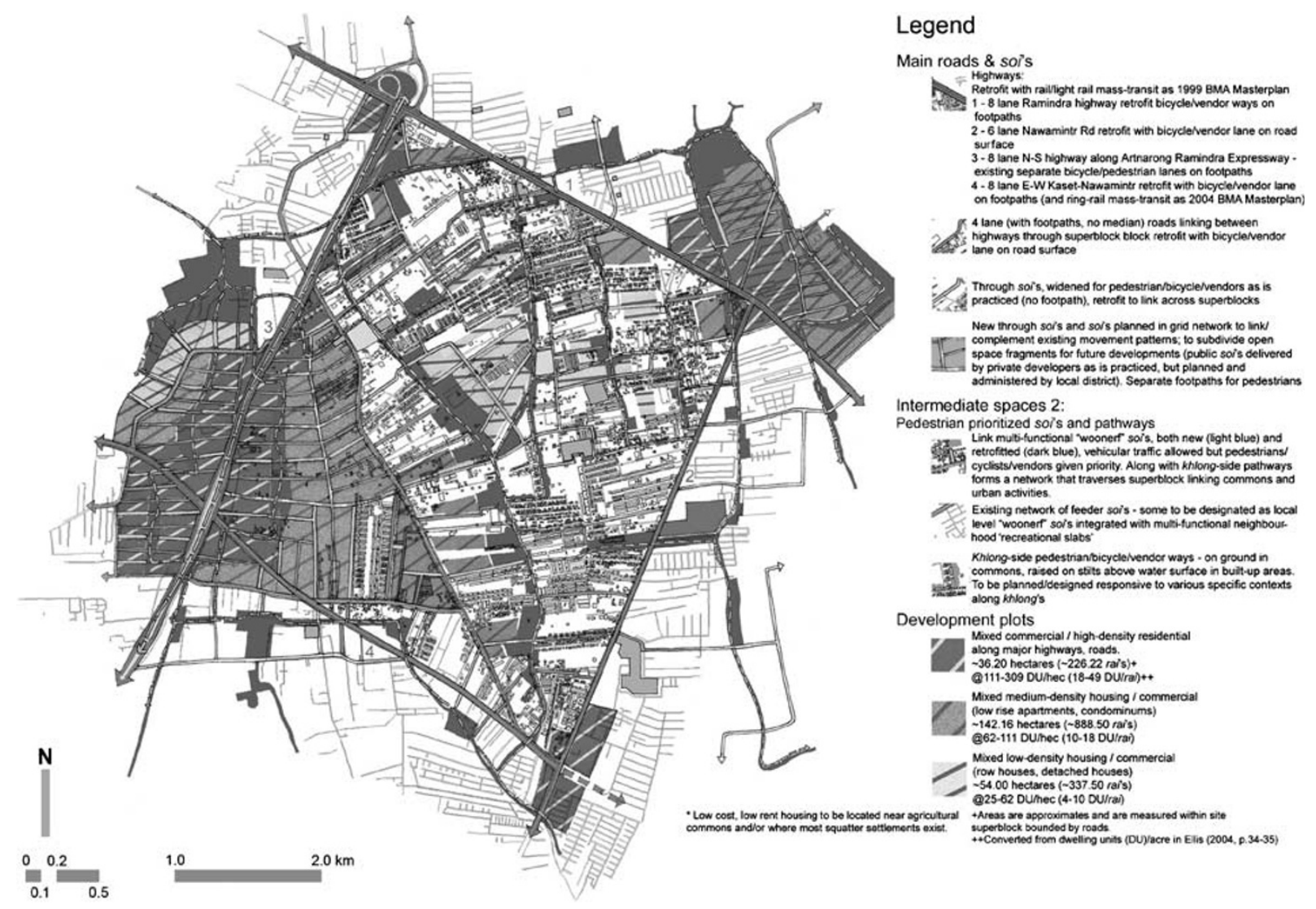

Figure 31. (Sub)urban development strategy.

such forms and applies them to the indigenous contexts of Bangkok's suburbanization. For instance, replacing the existing inefficient soi's (suburbanization 'on the cheap' - although by limiting access, addressing suburban 'security ${ }^{\prime 14}$ ) with the time-proven efficient grid road system would be costly and improbable. It is proposed here instead that the soi's be mitigated into a systemic network, coordinating, linking various suburban functions - to resemble a loose grid. The undesirable, undeveloped suburban fringes of open-space fragments and khlong's networks are translated into a coordinated system of ecological, agricultural and recreational green and blue stocks - a 'new' open-space typology. A system of vendorways, pedestrian and bicycle networks integrated into both systems of soi's and open spaces also combine characteristics of generic sustainable forms with local. The normative

\footnotetext{
${ }^{14}$ As access in and out of each development can be monitored by the local residents (if not controlled by security guards as at gated communities) - which arguable engenders a sense of community.
}

concepts of sustainability are thus manifested/ expressed in the localized forms of thanon's, soi's, superblocks, khlong's, paddies and orchards, tropical urban forests, wetlands, etc.

While the mediated alternative future scenario may be far from 'perfect' when assessed against the ideals of the Model for Sustainability, this is only to be expected as the model is introduced into, and mediated with, the site's peculiarities rather than imposed. It is argued that the design addresses and utilizes existing local ingredients and tools whether the forms of khlong's, openspace fragments, soi's, thanon's or slabs; the officially advocated planning tool of land readjustment; and the objectives as formally stated in the 1999 BMA masterplan. Through backcasting, it assumes a democratic, participatory politics (Maclaren, 1996; Girardet, 1999) rather than a topdown system of delivery, and is consistent with the principles of sustainable implementation by favoring a loose-structured form/process upon which local differences can be accommodated and custom design/planning detailed resolutions can 
be based. It also assumes that this is not an 'end product', rather an evolution as part of the sustainability process that is subjected to trial and error, monitoring progress and recess. Should the process be sustained for longer periods, scenarios that move closer to the Model for Sustainability is presumed.

As stated earlier, sustainability's meanings, forms and practices cannot be too dogmatic and thus impractical; yet, it also cannot afford to be too plastic and become irrelevant. Sustainability, while the broad-brush concept/tool to address global concerns, must be translatable and applicable to diverse local cultural, socio-economic and physical contexts to be critically influential in shaping each city's highly varied urban conditions and urbanization processes and practices.

\section{References}

Anukulyudhathon, E. (2004) Rapid growth and the fragility of urban ecology. Current Reflection of Society: Proceedings Silpakorn Architectural Discourse 3rd Symposium, Silpakorn University, Bangkok, Faculty of Architecture.

Bangprapa, M. (2004) Temple property exclusion agreed, Bangkok Post (internet edition issue 29th May: http://www.bangkokpost.com/News/29May 2004_news19.php). Bangkok.

Bello, W., Cunningham, S. and Poh, L.K. (1998) A Siamese Tragedy: Development and Disintegration in Modern Thailand. London: Zed Books Ltd.

Berke, P and Conroy, M.M. (2000) Are we planning for sustainable development? Journal of the American Planning Association, 66(1): 21-33.

BMA. (1999) Pang Muang Ruam Krungthep Mahanakorn (Bangkok Masterplan 1st revison) (in Thai). Bangkok: Department of City Planning, Bangkok Metropolitan Administration.

BMA. (2001) Statistical Profile of BMA. Bangkok: Department of Policy and Planning, Bangkok Metropolitan Administration.

Breheny, M.J. (ed.) (1992) Sustainable Development and Urban Form. London: Pion.

Bull, C. (2002) Contributing to ESD through landscape planning, design and management, Environment Design Guide, August 2002, DES 48, RAIA Publications, 2002, p. 1-5.

Campbell, S. (1996) Green cities, growing cities, just cities? Urban planning and the contradictions of sustainable development, Journal of the American Planning Association, 62(3): 296-312.

Carmona, M., Heath, T., Oc, T. and Tiesdell, S. (2002) Public Places - Urban Spaces: The Dimensions of Urban Design. Boston, MA: Architectural Press.

Clarke, P. (2003) Urban planning and design, in Thomas, R. (ed.) Sustainable Urban Design: An
Environmental Approach. New York: Spon Press, pp. 14-24.

Dearden, P. (2002) 'Dern Sai Klang' Walking the middle path to conservation in Thailand, in Dearden, P. (ed.) Environmental Protection and Rural Development in Thailand: Challenges and Opportunities. Bangkok: White Lotus Press.

Douglass, M. and Zoghlin, M. (1994) Sustaining cities at the Grassroots: livelihood, environment and social networks in Suan Phlu, Bangkok, Third World Planning Review, 16(2): 171-300.

DRTP. (2002) Bangkok District Development Plan: Bungkum District Proposed for the Department of City Planning, BMA (in Thai). Bangkok: Department of Regional and Town Planning, Faculty of Architecture, Chulalongkorn University.

DTCP. (1999) Karn Pungmuang nai Ratchasamai Phrabatsomdej Phrachaoyuhua Bhumiphol Adulyadej (Urban Planning in the Reign of King Bhumiphol Adulyadej) (in Thai). Bangkok: Department of Town and Country Planning.

Durand-Lasserve, A. (1980) Speculation on Urban Land, Land Development and Housing Development in Bangkok: Historical Process and Social Function 1950-1980. Paper presented in Thai-European Seminar on Social Change in Contemporary Thailand, 28-30 May.

DUDP. (1997) Bangkok District Development Plan: Bangkhen District Proposed for the Department of City Planning, BMA (Draft Final Report) (in Thai). Bangkok: Department of Urban Design and Planning, Faculty of Architecture, Silpakorn University.

Ellis, J.G. (2004) Explaining residential density, Places, 16(2): 34-43.

Frey, H. (1999) Designing the City: Towards a More Sustainable Urban Form. London; New York: E \& FN Spon.

Girardet, H. (1999) Schumacher Briefing No.2 Creating Sustainable Cities. Devon, UK: Green Books.

Hagan, S. (2001) Taking Shape: A New Contract Between Architecture and Nature. Oxford; Boston: Architectural Press.

Hanks, L.M. (1972) Rice and Man: Agricultural Ecology in Southeast Asia. Honolulu: University of Hawaii Press.

Hamilton, A. (2000) Wonderful, terrible: Everyday life in Bangkok, in Bridges, G. and Watson, S. (eds.) A Companion to the City. Oxford: Blackwell Publishers Inc. pp. $460-471$.

Herbert, D.T. and Thomas, C.J. (1997) Cities in Space: City as Place. London: David Fulton.

Hough, M. (1995) Cities and Natural Process. London; New York: Routledge.

Jaijongrak, R. (1974) Ruen Thai Derm (Traditional Thai House). Bangkok: Thammasat University Press.

Jumsai, S. (1997) Naga: Cultural Origins in Siam and the West Pacific. Bangkok: Chalermnit Press and DD Books.

Kaothien, U. and Webster, D. (2000) The Bangkok region, in Simmonds, R. and Hack, G. (eds.) Global City Regions: Their Emerging Forms. London: EXFN Spon, pp. 23-37. 
Kaufman, H.K. (1976) Bangkuad A Community Study in Thailand. Rutland and Tokyo: Charles E. Tuttle Company, Inc.

Kemgumnerd, T. (2002) Dykes worsen problem as river heads for record, Bangkok Post (internet edition issue 2nd October: http:/ /www.bangkokpost.com/ 021002_News/02Oct2002_news05.html). Bangkok.

Maclaren, V.W. (1996) Urban sustainability reporting, Journal of the American Planning Association, 62(2): 184 (19).

Nassauer, J.I. (1995) Messy ecosystems, orderly frames, Landscape Journal, 14(2): 161-170.

Newman, P. and Kenworthy, J. (1999) Sustainability and Cities. Washington, DC: Island Press.

Nicholson-Lord, D. (1987) The Greening of the Cities. London; New York: Routledge \& Kegan Paul.

Nimlek, S. (2002) SatapatayakamPhuenThin RuenChaoSuan (Vernacular Architecture Plantation Houses) (in Thai). Bangkok: Thammasat University Press.

Papanek, V.J. (1995) The Green Imperative: Natural Design for the Real World. New York: Thames and Hudson.

Prachachat. (2004) Landlords rejoice BMA unlocks new masterplan (in Thai), Prachachat Thurakij (internet edition issue 8th March: http://www.matichon. co.th/prachachat/prachachat.php? show $=1 \&$ selectid $=02$ p0107080347\&sectionid $=0201 \&$ select_date $=2004 /$ 03/08 ). Bangkok: 1.

Robinson, I.M. (1995) Emerging spatial patterns in ASEAN mega-urban regions, in McGee, T. G. and Robinson, I. M. (eds.) The Mega-Urban Regions of Southeast Asia. Vancouver: UBC Press, pp. 78-108.

Rogers, R.G. (1997) Cities for a Small Planet. London: Faber.

Sintusingha, S. (2004) Bangkok: sustainable sprawl? NaJua: Journal of the Faculty of Architecture Silpakorn University, 20(2003-2004): 139-148.

Spirn, A.W. (1984) The Granite Garden: Urban Nature and Human Design. New York: Basic Books.
Steinitz, C. (ed.) (1998) Alternative Futures in the Western Galilee, Israel. Boston: Havard University Graduate School of Design.

Sternstein, L. (1982) Portrait of Bangkok. Bangkok: Bangkok Metropolitan Administration.

Thairath. (2004) 41 Ongkorn Phuddhasasna karn kormor jadrhubteedin (41 Buddhist Organizations protest Land readjustment Bill), Thairath (internet edition issue 27th May: http:/ /www.thairath.co.th/thairath1/ 2547/educat/apr/08/edu1.php). Bangkok.

Thansettakij. (2004) Perd jai Sawang Srisakhun pud 'muang mai nai fan' yark ying gwa khen krok kun phukhao (Interview with Sawang Srisakhun: It is extremely hard to build a 'dream city'), Thansettakij (internet edition issue 16th-19th May: http:// 203.107.133.147/than2000/1905/columninterview4.htm) Bangkok.

Rees, W. (1999) Scale, complexity and the conundrum of sustainability, in Kenny, M. and Meadowcroft, J. (ed.) Planning Sustainability. London; New York: Routledge, pp. 101-127.

Vichit-Vadakan, V. and Nakata, T. (eds.) (1976) Urbanization in the Bangkok Central Region. Bangkok: Thai University Research Associate: The Social Science Association of Thailand.

Wolch, J., Wilson, J.P. and Fehrenback, J. (2002) Parks and park funding in Los Angeles: An equity mapping analysis. Los Angeles, Sustainable Cities Program and GIS Research Laboratory, University of Southern California.

Yeang, K. (1986) The Tropical Veranda City: Some Urban Design Ideas for Kuala Lumpur. Kuala Lumpur: Asian Publications.

Yeang, K. (2002) Reinventing the Skyscraper: A Vertical Theory of Urban Design. Chichester: Wiley-Academy.

Yencken, D.G.D. and Wilkinson, D. (2000) Resetting the Compass: Australia's Journey Towards Sustainabilty. Collingwood, VIC: CSIRO Publishing. 